\title{
Prava živog svijeta i etičnost čovjekova djelovanja prema prirodnom svijetu
}

\author{
Tijana Trako Poljak
}

Filozofski fakultet Sveučilišta u Zagrebu, Odsjek za sociologiju, Hrvatska e-mail: ttrako@ffzg.hr

\section{Ivan Cifrić}

Zagreb, Hrvatska

\author{
Antonija Bukvić-Letica \\ Zagreb, Hrvatska
}

\section{Tea Tomić}

Zagreb, Hrvatska

SAŽETAK Ekološki problemi suvremenog društva ne mogu se niti pokušati razumjeti niti rješavati bez dubljeg razumijevanja etičkih principa koji vode donošenje odluka uključenih aktera. Odnosom čovjeka prema okolišu, a time i njegovim praktičnim djelovanjem prema živom i neživom svijetu koji ga okružuje, upravljaju etički principi koji potpadaju pod antropocentričke i eko/biocentričke orijentacije. Cilj je rada istražiti etičke perspektive hrvatskih građana/ki prema živom svijetu, i to kroz njihovu percepciju: 1) prava živih bića na život i 2) motiva čovjekove brige za živi svijet (biljke i životinje). U teorijskom dijelu rada ideja "prava živog svijeta na život" određuje se kroz tri postojeća dominantna pristupa: (biološki) egalitarizam, antropocentrički ekscepcionalizam (čovjekova dominantnost) i borba vrsta za opstanak (prirodna kompetitivnost). Nadalje, „motivi čovjekova postupanja prema živom svijetu“ definiraju se kroz četiri ključna etička pristupa: deontološka etika (etika dužnosti), utilitarna etika (etika korisnosti), etika emotivnosti (osjećaji) i situacijska etika (okolnosti). U metodološkom dijelu rada prikazani su rezultati empirijskog istraživanja provedenog na reprezenta- 
tivnom uzorku hrvatskih građana/ki (2014.; $\mathrm{N}=1000$ ). Rezultati pokazuju da u svijesti većine ispitanika prevladava: 1) egalitarizam kao pravo na život (životinjske vrste imaju jednako pravo na život kao i čovjek) i 2) deontološka etika kao motiv čovjekova postupanja prema živom svijetu, s time da postoje određene statistički značajne razlike s obzirom na ispitana sociodemografska obilježja. Na kraju se daje i kraća usporedba dobivenih rezultata s rezultatima ranije provedenih istraživanja na užoj studentskoj populaciji (2005., 2007., 2010.).

Ključne riječi: antropocentrizam, ekocentrizam, prava životinja, egalitarizam, deontološka etika.

\section{Uvod ${ }^{1}$}

Suvremena socijalno-ekološka kriza i sve veća ugroženost biološke raznolikosti stavlja pred sociologe zadatak boljeg razumijevanja odnosa čovjeka (društva) prema prirodnom svijetu koji ga okružuje. Od druge polovice 20. stoljeća do danas sve se više govori o temama vezanim za ekološku krizu koju je uzrokovao čovjek, pri čemu u društveno-humanističkom području najznačajniji doprinos takvim raspravama daju socijalna ekologija (engl. environmental sociology), bioetika i druge povezane znanstvene grane kao što je etika okoliša (engl. environmental ethics) i sl. Međutim još je uvijek osjetan manjak istraživanja koja bi dala empirijske temelje za bolje razumijevanje čovjekova odnosa prema drugim oblicima života, njegovu su-svijetu. Cilj je ovog rada istražiti percepciju prava živog svijeta na život i etičnost u motivima koji upravljaju praktičnim djelovanjem čovjeka prema živom svijetu na primjeru hrvatskog društva. Rezultati provedenog empirijskog istraživanja na reprezentativnom uzorku hrvatskih građana/ki (2014; N = 1000) trebaju poslužiti produbljenju razumijevanja odnosa hrvatskog društva prema živom svijetu koji nas okružuje, ali potencijalno i otvoriti prostor za smjernice za praktično djelovanje, koje bi kroz edukaciju ili određene politike mogle pomoći unaprjeđenju tog odnosa.

U prvom teorijskom dijelu rada bit će predstavljene glavne teorijske postavke istraživanja. Središnja je tema istraživanja „živi svijet“, „Život“, odnosno percepcija čovjekova odnosa i praktičnog postupanja prema živom svijetu, pa je istraživački instrument sastavljen tako da su operacionalizirane dvije dimenzije: „pravo živog svijeta na život“ i „motivi čovjekova postupanja prema živom svijetu“. Postavljenim tvrdnjama o čovjekovu pravu i pravu ostalih živih bića na život pokušala su se konkretizirati tri teorijska pristupa pravima koja dominiraju u postojećoj literaturi: 1) (biološki) egalitarizam (u živom svijetu), 2) čovjekova izuzetost ili segregacija (antropološki ekscepcionalizam) i 3) kompetitivnost ili borba vrsta za opstanak (evolucionizam). Nadalje, uz percepciju prava bilo je važno ispitati i motive čovjekove brige za živi svijet, s obzirom na to da načelan odnos pojedinca prema su-svijetu nije uvijek sukladan njegovom ponašanju u konkretnim situacijama. Na temelju postojeće literature motive čovjekova postupanja prema živom svijetu moguće je analizirati iz različitih etičkih aspekata, od kojih smo operacionalizirali sljedeća četiri najistaknu-

1 Dio rezultata istraživanja predstavljenog u radu izneseni su na međunarodnom znanstvenom skupu „13. lošinjski dani bioetike“ 2014. godine. 
tija: 1) etika dužnosti (deontologija), 2) etika korisnosti (utilitarizam), 3) etika emotivnosti ili osjećajnost te 4) situacijska etika (okolnosti). Istraživački je instrument na kraju bio sastavljen od sedam tvrdnji: za „pravo živog svijeta na život“ postavljene su tri tvrdnje, a za „motive čovjekova postupanja prema živom svijetu“ postavljene su četiri tvrdnje, povezane s navedenim etičkim pristupima, koje cemo detaljnije elaborirati u teorijskim postavkama rada. U drugom, metodološkom dijelu rada uz metodološke postavke bit će iznijeti rezultati provedenog empirijskog istraživanja kroz prikaz općih distribucija rezultata te njihove korelacije sa sociodemografskim obilježjima i orijentacijama ispitanika. U diskusiji empirijskih rezultata oslanjamo se na iznesenu teorijsku podlogu rada. Na kraju, bit će prikazana i kraća usporedba dobivenih rezultata s rezultatima sličnih istraživanja koja su autori ranije proveli na užoj studentskoj populaciji (Cifrić, 2005.; Cifrić, 2007.a; Cifrić i Trako Poljak, 2010.).

\section{Teorijske postavke}

\subsection{Pravo živog svijeta na život}

Trebaju li životinje imati prava iako nisu osobe? Treba li im pripisati sva prava koja uživaju i ljudi ili samo neka? Trebaju li pod zaštitu prava potpasti sve životinje ili samo neke vrste? To su samo neka od pitanja koja se javljaju u postojećoj socijalno-ekološkoj literaturi kada se raspravlja o pravima životinja. U pokušaju davanja odgovora na njih autori zastupaju čitav spektar ideja. Kako bismo operacionalizirali postojeća stajališta za naše istraživanje, odabrali smo tri dominantna pristupa u literaturi koja stoje na samim krajevima tog spektra. Prvi: radi se o autorima eko/ biocentrizma, koji traže da se životinjama omoguće jednaka prava kao i čovjeku jer posjedovanje razuma i višeg oblika svijesti kojim se čovjek izdvaja od ostatka životinjskoga svijeta ne smatraju relevantnim kriterijima za zauzimanje posebnog statusa u odnosu na druge vrste u prirodi. Drugi: neki autori zagovaraju pristup prema kojem se sve treba prepustiti prirodi, odnosno prema kojem svaka vrsta treba imati onoliko prava koliko uspije za sebe izboriti. I treći: tu je grupa autora koji zagovaraju antropocentrički pristup kojim se apsolutno protive davanju ikakvih prava životinjama, odnosno zauzimaju se za zadržavanje zakonske zaštite isključivo za ljude. Drugim riječima, s obzirom na pretpostavku o tome koja od živih bića imaju koliko pravo na život u odnosu na ostale, a prije svega čovjeka, jasno se mogu diferencirati sljedeća tri pristupa: biološki egalitarizam, borba vrsta za opstanak i antropološki ekscepcionalizam.

\subsubsection{Biološki egalitarizam}

Tezu biološkog egalitarizma ili jednakosti živog svijeta u prirodi preuzimamo od jednog od njenih najistaknutijih predstavnika Arnea Naessa, koji ju razvija od 1970-ih godina u sklopu svoje „dubinske ekologije“ (engl. deep ecology). Sličnu ideju kasnije zastupaju i drugi autori kao što su Paul Shepard (1996., 1997.), George Sessions (1995.), Bill Devall (2001.), Theodore Roszak (1995.), Dolores La Chapelle (1991.) 
i ostali zagovornici tzv. „nove ekološke etike“. Naess osnovni uzrok ekološke krize vidi u ekscesima do kojih je dovela suvremena paradigma industrijskog napretka i ekonomskog razvoja, a koja se temelji na čovjekovoj neograničenoj manipulaciji prirodom i okolišem. Pri tome rješenje traži u radikalnoj promjeni čovjekova mišljenja o živom svijetu i okolišu i postupanja prema njemu. Jedna je od radikalnih Naessovih ideja i tzv. „biosferni egalitarizam u načelu“ (engl. biospherical egalitarianism - in principle), odnosno biosferna jednakost koju u radu operacionaliziramo kao biološki egalitarizam. U osnovici biološkog egalitarizma shvaćanje je da svaki entitet - biće, vrsta - posjeduje tzv. intrinzičnu ili vlastitu vrijednost (engl. own value, njem. Eigenwert), vrijednost u/po samom sebi (engl. value in itself). Intrinzična je vrijednost neovisna o čovjekovoj procjeni vrijednosti drugog bića ili vrste. Jednakost bića i vrsta u prirodi proizlazi, dakle, iz njihove sposobnosti da se u svoj punini realiziraju takvi kakvi jesu, onako kako im je priroda namijenila (engl. self-realization). Međutim Naess dodaje „u načelu“ kako bi naglasio da ne odbacuje činjenicu kako je čovjekova „sudbina“ da stoji na vrhu evolucijske piramide. No čovjek katkad treba ustuknuti sa svojim potrebama i prohtjevima pred potrebama drugih vrsta, naročito kada se „dimenzija perifernih ljudskih potreba usporedi s vitalnim potrebama drugih vrsta, ako su u konfliktu“"(Naess, 1989.:171; vidi i: Naess, 1973.).

\subsubsection{Borba vrsta za opstanak}

Druga teza, borba vrsta za opstanak, ili teza prirodne kompetitivnosti vrsta, podrazumijeva da svaka vrsta pa i ljudska ima onoliko prava na život koliko si sama uspije izboriti. Oslanja se na teoriju evolucije Charlesa Darwina (2008. [1859.]), prema kojoj su selekcija i eliminacija temeljni načini odabira unutar vrste, a preživljavanje ovisi o sposobnosti prilagodbe i uspješnosti borbe s drugim vrstama. Tako su i čovjek / ljudska vrsta također suočeni s borbom za vlastiti opstanak. Uvodeći i socijalni aspekt, Ivan Cifrić (2006.) ističe kako tu borbu možemo promatrati kroz tri dimenzije: 1) unutar biotičke ekumene (prirodne zajednice), 2) unutar kulturne ekumene (sfera čovjekova djelovanja) i 3) između kulturne ekumene i biotičke ekumene. Rezultat tih triju dimenzija sukoba, prema Cifriću, čovjekov je kulturni razvoj jer koncepcije razvoja nisu ništa drugo nego koncepcije strategija opstanka, odnosno borbe „kulturnog bića“ s prirodom. A druga, mračnija strana medalje razvoja čovječanstva suvremena je socijalno-ekološka kriza (Cifrić, 2006.).

\subsubsection{Antropološki ekscepcionalizam}

Ukorijenjenost antropocentričke ideje o čovjekovoj nadređenosti prirodi, koju u radu nazivamo tezom antropološkog ekscepcionalizma, proizlazi iz triju glavnih ishodišta: a) religijskog, b) evolucijskog i c) racionalnog. U religijskom smislu, čovjekova izuzetost od drugih živih vrsta u abrahamskim religijama vidljiva je, primjerice, u kršćanstvu u biblijskoj knjizi Postanka: „Plodite se, i množite, i napunite zemlju i sebi je podložite“ (Post 1,28). Taj se stih obično tumači Božjim ovlaštenjem čovjeka da sebi podloži zemlju i bude gospodar svega na njoj, što je indirektno blagoslov za 
vladanje na Božjem imanju. U sekularnom smislu, tvrdnja o većim čovjekovim pravima na život od ostalih neljudskih bića argumentira se dvama (povezanim) argumentima: čovjekove izuzetnosti (engl. exceptionalism) i čovjekove izuzetosti (engl. exemptionalism). Izuzetnost proizlazi iz svojstava koja čovjek kao vrsta posjeduje u odnosu na druge vrste. Čovjek se smatra sastavnim dijelom zemaljske „Životne zajednice” ili „biosferne zajednice”, međutim u njoj on hijerarhijski zauzima mjesto na vrhu piramide, te mu otuda i veće pravo. U racionalnom smislu radi se o „paradigmi čovjekove izuzetosti“ (engl. human exemptionalism paradigm - HEP), kojom se zagovara čovjekova izdvojenost, segregiranost od ostatka prirode i dominacija nad ostalim živim bićima zbog njegovih izuzetnih sposobnosti, prije svega sposobnosti razvijanja kulture (simboličkog mišljenja) kao osnovnog kriterija. Njegova izuzetost od svijeta prirode pretpostavlja odvojenost ili dihotomnu suprotstavljenost čovjeka i prirode, nadređenost kulture/društva prirodi, čovjekovu subjektivnost i slobodu, pa mu otuda i veće pravo. U odnosu na HEP, 1978. godine Riley E. Dunlap i Kent D. Van Liere razvijaju egalitarniji pristup kroz „novu ekološku paradigmu“ (engl. new environmental paradigm - NEP) i mjernu skalu, na čije se rezultate oslanjamo kod postavljanja hipoteza i u ovom istraživanju.

\subsection{Motivi postupanja prema živom svijetu}

Motivi postupanja prema živom svijetu definirani su kroz četiri prevladavajuće etičke pozicije koje upravljaju čovjekovim praktičnim djelovanjem: deontološka etika (etika dužnosti), utilitarna etika (etika korisnosti), etika emotivnosti (osjećaji) i situacijska etika (okolnosti). Deontološka etika ili etika dužnosti odnosi se na čovjekovu brigu o biljkama i životinjama koja proizlazi iz njegove dominantnosti nad prirodom. Čovjek kao biće na vrhu evolucijske piramide odgovoran je i slobodan, te treba voditi brigu o onima koji se nalaze niže na toj hijerarhijskoj piramidi. Prema drugom tipu motivacije, korisnosti ili utilitarizmu, impliciranom i u prethodnom tipu, čovjek ujedno ovisi o onima koji se nalaze niže od njega na evolucijskoj ljestvici, što predstavlja jedan od ključnih motiva njegove brige ili odnosa prema prirodi. Tako je briga za životinje i biljke recipročna našem očekivanju koristi od njih. Budući da čovjek nije samo ens cogitans nego je i ens amans, izdvajamo i treći, emotivni aspekt motivacije odnosa čovjeka prema biljkama i životinjama. U osjećajnost kao motivaciju uključeni su, primjerice, i važnost estetike te čovjekova potreba za igrom i društvenošću kao razlozi zbog kojih ljudi brinu o svom živom su-svijetu. Konačno, motiviranost situacijom podrazumijeva postojanje različitih okolnosti koje uvjetuju čovjekov odnos i kojima ga čovjek opravdava. S obzirom na spektar od antropocentričkih do eko/biocentričkih orijentacija, navedene etičke pristupe možemo poslagati po sljedećem redu: korisnost kao najsnažnija antropocentrička motivacija, zatim okolnosti, pa emotivnost kao kretanje prema eko/biocentrizmu te dužnost kao najbliža eko/biocentrizmu. 


\subsubsection{Deontološka etika}

Deontološka etika ili etika dužnosti potječe od Immanuela Kanta (1999. [1785.]) i dužnost stavlja iznad (čovjekovih) prava (u ekološko-etičkom smislu razvijaju je i drugi autori kao npr. Tom Regan, 2004.). Naime iako samo čovjek posjeduje intrinzičnu vrijednost, njegova pozicioniranost na vrhu piramide uz prava koja to sa sobom nosi podrazumijeva i određene obveze prema njegovom su-svijetu. Dakle osim izravne dužnosti prema drugom čovjeku čovjek ima i neizravnu dužnost voditi brigu o ostatku živog svijeta. S obzirom na problem rješavanja ekološke krize, kojoj je sam pridonio, on ima etičku dužnost voditi brigu o svom okolišu koji je sve više ugrožen, kako zbog sebe tako i zbog budućih generacija (antropocentrička motivacija). Međutim iako proizlazi iz tog antropocentričkog shvaćanja, etika dužnosti može se razviti i iz respekta života kao takvoga, koji čovjek nije sam stvorio, odnosno zbog davanja intrinzične vrijednosti životu uopće (biocentrizam).

\subsubsection{Utilitarizam}

Drugi tip motivacije, utilitarni, određujemo kao princip koristi, odnosno (kvantitativno i kvalitativno) prevladavanje koristi nad štetom uzimajući u obzir sve uključene na koje će neka odluka utjecati. Briga o životinjama te biljkama recipročna je očekivanju koristi od njih. Tako se čovjekovo postupanje prema živom svijetu promatra kroz vaganje koristi koju od njih može imati u odnosu na štetu, žrtvu koju druga bića/vrste pri tome moraju podnijeti. Primjerice, laboratorijska istraživanja nad životinjama mogu se provoditi, no samo ukoliko njihovo korištenje maksimizira korist u odnosu na štetu, nepristrano uvažavajući interese i ljudi i životinja. Hipotetski, što je veća korist trebala bi biti i veća vjerojatnost da će ljudi više skrbiti o svom su-svijetu, no praksa ne potvrđuje takav stav. Kao što zaključuje Visković (2009.:317), „Životinje su samo stvari i sredstva ljudskih ciljeva i bez bilo koje kakve inherentne vrijednosti, tj. vrijednosti po sebi, koja može konkurirati potrebama i vrijednosti ljudi“. Čovjek živi svijet percipira kao prirodni resurs koju mu stoji na raspolaganju i od kojeg može imati korist. Tu korist može imati od organizama: (a) dok su živi (domestikacija životinja - rad, zabava, ugled, ukras, održanje biološke ravnoteže i sl.), ali i (b) kad su mrtvi (hrana, građevni materijal i dr.) (Cifrić i Trako Poljak, 2012.).

\subsubsection{Emotivnost}

Životinje i biljke izazivaju različita emotivna stanja (sućut), estetske dojmove (ljepota), potrebu za društvenošću (npr. zabava, igra), osobne asocijacije (npr. uspomene) ili stanovite identifikacije, i iz tih razloga ljudi brinu o biljkama i životinjama (Cifrić i Trako Poljak, 2012.). Stoga je jedan od snažnih motiva za brigu o biljkama i životinjama emotivnost ili osjećajnost. Osjećanjem prema živom svijetu čovjek mu pridaje i priznaje inherentnu vrijednost (za razliku od intrinzične), odnosno postojanje osjećaja koje i sam posjeduje. Kao što i drugi ljudi u nama pobuđuju različite osjećaje, tako i različite vrste biljaka i životinja izazivaju razne osjećaje (neke su 
umiljate i lijepe, druge ružne i opasne itd.), zbog čega su i reakcije brige o živom svijetu različite. Tako biljke i životinje kod ljudi mogu izazvati pozitivne emocije koje potiču etiku sućuti, no mogu izazvati i negativne emocije kao što su gađenje, strah, mržnja i slično, što može rezultirati čovjekovim nasilnim i nemoralnim ponašanjem. Primjerice, prema kućnim ljubimcima gajimo veću privrženost nego prema divljim životinjama, a u skladu s tim češće imamo snažnije osjećaje prema jedinkama nego cijelim vrstama, pa ćemo tako možda više preferirati svog psa nego sve pse i pasmine koje postoje. Slično je vidljivo i kod, primjerice, biljaka koje čovjek sam uzgoji ili koje se nalaze u njegovu neposrednom okružju, za razliku od nekih koje su možda daleke i tuđe. Emotivnost kao motivacija ponašanja prema živom svijetu proizlazi iz antropocentrizma, nalazimo ju i u eko/biocentrizmu, odnosno patocentričnoj etici, koju povezujemo s konceptom morala sućuti (Singer, 1998.).

\subsubsection{Situacijska etika}

Naposljetku, kod motiviranosti situacijom različite okolnosti uvjetuju i opravdavaju čovjekov različit odnos prema biljkama i životinjama. Sukladno stajalištu situacije ili okolnosti, prema životinjama i biljkama čovjek postupa različito, ovisno o trenutku, situaciji u kakvoj se nalaze životinje ili biljke ili u kakvoj se nalazi čovjek koji teži zadovoljiti neke svoje potrebe. Kroz kulturnu povijest čovjek je oduvijek koristio živi svijet oko sebe: za ogrjev ili građevni materijal, za hranu, u umjetnosti i zabavi, u religiji itd. (vidi npr.: Visković, 1996., 2001.). Ovisno o potrebi, čovjek (društvo, kultura), dakle, žrtvuje dijelove životinjskog i biljnog svijeta. Danas to žrtvovanje prelazi granice održivosti (obnovljivosti) živoga svijeta. Sama ta činjenica govori o tome na koji način čovjek doživljava sebe i svoje potrebe te koju im važnost pridaje u odnosu na ono što ga okružuje. Radi se, dakle, o antropocentričkom principu, po kojem čovjek svoje potrebe stavlja hijerarhijski iznad živog svijeta koji ga okružuje, i to radi zadovoljavanja ne samo svojih primarnih egzistencijalnih već i sekundarnih/ tercijarnih potreba.

\section{Metodologija}

\subsection{Provedba istraživanja}

Kvantitativno empirijsko istraživanje provedeno je metodom ankete 2014. godine na reprezentativnom uzorku građana/ki Republike Hrvatske $(\mathrm{N}=1000)$. Anketiranje je provedeno pisanim putem pomoću upitnika koji su izradili autori, a provela ga je agencija „GfK - center for market research“ kao dio šireg istraživanja. Nitko nije imao utjecaj na istraživanje i njegove rezultate. 


\subsection{Mjerni instrumenti}

Dio šireg istraživanja predstavljen u ovom radu sastojao se od dvaju instrumenata: „pravo živog svijeta na život“ i „motivi postupanja prema živom svijetu“. Prvi se instrument sastojao od triju, a drugi od četiriju čestica kojima su autori operacionalizirali postojeće najistaknutije teorijske pravce vezane za te dvije dimenzije čovjekova odnosa prema živom svijetu: 1) za „pravo živog svijeta na život“ tri teorijska pristupa: egalitarizam (biološki egalitarizam u živom svijetu), antropocentrički ekscepcionalizam (čovjekova dominacija) i borba vrsta za opstanak (prirodna kompetitivnost); a 2) za „motive čovjekove brige za živi svijet“ četiri etička pristupa: deontološka etika (dužnost), utilitarna etika (korisnost), etika emotivnosti (osjećaji) i situacijska etika (okolnosti). Radilo se o peterotomnim skalama (ne)slaganja. Uz to, ispitana su i osnovna sociodemografska obilježja ispitanika: spol, dob, veličina mjesta prebivanja ispitanika, regionalna pripadnost, (samo)procjena imovinskog statusa i stupanj obrazovanja. Mjerni instrument konstruiran je na Katedri za socijalnu ekologiju Odsjeka za sociologiju Filozofskog fakulteta u Zagrebu, pod vodstvom prof. dr. sc. Ivana Cifrića. Autori su isti instrument prethodno koristili u provedbi istraživanja na užoj studentskoj populaciji (Cifrić, 2005.; Cifrić, 2007.a; Cifrić i Trako Poljak, 2010.).

\subsection{Uzorak}

Istraživanje je provedeno na reprezentativnom uzorku građana/ki Republike Hrvatske $(\mathrm{N}=1000)$. Uzorak je dvostruko stratificiran prema regiji i veličini mjesta. Ispitanici su odabrani metodom posljednjeg rođendana, a u uzorak su ušli ispitanici od 15 godina naviše. Greška je uzorka 3,1\%.

\subsection{Obrada podataka}

Rezultati istraživanja obrađeni su i analizirani pomoću statističkog programa SPSS 24,0. U obradi i analizi podataka primijenjene su metode univarijatne (postoci) i bivarijatne (Pearsonova korelacija, analiza varijance i t-test) statistike.

\subsection{Hipoteze}

Postavili smo dvije glavne hipoteze povezane s dvama glavnim ispitanim instrumentima („pravo živog svijeta na život“ i „motivi čovjekove brige za živi svijet“), dok je treća hipoteza vezana za korelaciju odgovora sa sociodemografskim obilježjima ispitanika.

Glavna hipoteza za prvi instrument o „pravu živog svijeta na život“ glasi:

H1 - Hrvatski/e građani/ke najviše će se složiti s tvrdnjom da svaka životinjska vrsta ima jednaka prava na život kao i čovjek. 
Pretpostavili smo da među hrvatskim građanima/kama postoji određena senzibilnost za pitanja o pravima životinja, na što upućuju i ranija istraživanja, koja pokazuju prevladavajući ekocentrički stav kod socioekoloških orijentacija naših građana u odnosu prema okolišu (vidi npr.: Cifrić, 2004.).

Za drugi instrument o „motivima postupanja prema živom svijetu“ postavljena je sljedeća glavna hipoteza:

H2 - Većina hrvatskih građana/ki preferirat će „dužnost“, a znatno manji broj „korisnost“, „emocije“ ili „situaciju“ kao motivaciju za čovjekovo postupanje prema živom svijetu.

Smatrali smo kako se može očekivati da se percepcija građana/ki o vrijednosti prirodnog svijeta dominantno temelji na potrebi njegova očuvanja, a ne samo na temelju koristi ili uvjetovanosti određenim situacijama. Ta se pretpostavka također temeljila na činjenici da ranija istraživanja pokazuju prevladavajući ekocentrički stav kod socioekoloških orijentacija naših građana u odnosu prema okolišu (vidi npr.: Cifrić, 2004.), a etika dužnosti najuže je povezana s eko/biocentričkim postavkama za razliku od ostalih triju ispitanih etičkih motivacija, koje su nešto više ili u potpunosti antropocentričke.

S obzirom na sociodemografska obilježja i orijentacije ispitanika postavljena je sljedeća hipoteza, koja se sastoji od nekoliko podhipoteza za svako zasebno sociodemografsko obilježje:

H3 - Žene, mlađi ispitanici, ispitanici višeg stupnja obrazovanja, iz većih gradova i regija koje su politički liberalnije orijentirane te ispitanici koji procjenjuju svoj imovinski status kao prosječan ili iznad prosjeka statistički će značajno više preferirati biološku egalitarnost kod prava živog svijeta na život te dužnost kod motiva postupanja prema živom svijetu. Odnosno muškarci, stariji ispitanici, nižeg stupnja obrazovanja, ispitanici iz manjih mjesta i konzervativnije orijentiranih regija te oni koji procjenjuju svoj imovinski status ispod prosjeka bit ce skloniji antropocentričkom i instrumentalnom odnosu čovjeka prema živom svijetu - antropološki ekscepcionalizam u odnosu na biološki egalitarizam u pravima i utilitarizam i situacijsku etiku u odnosu na etiku dužnosti u motivima.

Hipoteze vezane za sociodemografska obilježja ispitanika temelje se na istraživanjima koja pomoću mjerne skale „nove ekološke paradigme“ (NEP) od 1978. razvijaju Dunlap i Van Liere. Van Liere i Dunlap (1980.) tako iznose sljedeće hipoteze, koje se u kroskulturalnim istraživanjima koja se otada provode i potvrđuju: engl. age hypothesis, sex hypothesis, residence hypothesis, political hypothesis i social class bypothesis. Odnosno, s obzirom na hipotezu vezanu za dob, mlađi su ispitanici više proekološki orijentirani od starijih. I prijašnja istraživanja koja su autori proveli na ovu temu na studentskoj populaciji, uključujući ono iz 2005. godine (Cifrić, 2007.a) te iz 2010. godine (Cifrić i Trako Poljak, 2012.), također su pokazala da mladi najviše podržavaju ekocentrički, a ne antropocentrički pristup, odnosno egalitarizam kod prava živoga svijeta te dužnost kod motiva čovjekove brige i postupanja prema živom svijetu. Veličina mjesta stanovanja također se pokazala značajnom varijablom $\mathrm{u}$ istraživanjima proekoloških stavova, odnosno urbani u odnosu na ruralne prostore 
više su proekološki orijentirani. Nadalje, dok Dunlap i Van Liere govore o političkoj orijentaciji, regionalna pripadnost koju smo ispitali u istraživanju više se tiče sociološkog shvaćanja vrijednosti, odnosno regija koje više zastupaju tradicionalne ili moderne vrijednosti, što smo također smatrali da ima snažnog utjecaja na proekološke stavove (za analizu tradicionalnih, modernih i postmodernih/materijalističkih vrijednosti u glavnim hrvatskim regijama vidi npr., Cifrić, 1996.; Cifrić 2007.b; Cifrić, Trako Poljak i Klasnić, 2013.; Ilišin, 2016.). Prema hipotezi društvenog položaja, sklonost proekološkim stavovima i ponašanju usko je povezana s višim društvenim položajem ispitanika. Konačno, jedina razlika u postavljanju naše hipoteze u odnosu na Dunlapa i Van Lierea odnosi se na spol. Dok oni navode kako još uvijek nema dovoljno istraživanja koja bi pokazala postoji li razlika između žena i muškaraca s obzirom na proekološke stavove i ponašanje, kasnija istraživanja većinom su pokazala da značajne razlike postoje, i to u korist žena (vidi npr.: Zelezny i sur., 2000.). U istraživanjima u nas (vidi npr.: Cifrić, 2004., 2006.) žene su također statistički značajno više ekocentrično orijentirane od muškaraca.

\section{Rezultati istraživanja}

U prikazu rezultata istraživanja za dvije ispitane dimenzije, „pravo živog svijeta na život“ i „motivi čovjekova postupanja prema živom svijetu“ predstavit ćemo opće distribucije rezultata (aritmetičke sredine, standardne devijacije i postoci), korelaciju čestica koje čine te dvije dimenzije te razlike u prosjecima s obzirom na sociodemografska obilježja. Opće distribucije prikazane su kao ilustrativne o smjeru rezultata, odnosno hipoteze smatramo potvrđenim ili odbačenim isključivo na temelju pronađenih statistički značajnih podataka (u tablicama su zbog prostora kod rezultata t-testa i ANOVA-e prikazani samo statistički značajni podaci).

\subsection{Opće distribucije rezultata za "pravo živog svijeta na život" $i$ "motive čovjekova postupanja prema živom svijetu"}

Tablica 1.

Aritmetičke sredine odgovora za „pravo na život“ i „motive postupanja prema živom svijetu“ (M)

\begin{tabular}{|c|c|c|c|}
\hline & TVRDNJE & M & sd \\
\hline \multirow{3}{*}{$\begin{array}{c}\text { PRAVO ŽIVOG } \\
\text { SVIJ̈ETA NA } \\
\text { ŽIVOT }\end{array}$} & Svaka Životinjska vrsta ima jednako pravo na život kao i čovjek & 3,88 & 1,042 \\
\hline & Čovjek ima veće pravo na život od životinjskih vrsta & 3,14 & 1,262 \\
\hline & Svaka vrsta ima onoliko prava koliko izbori u odnosu na druge vrste & 3,11 & 1,014 \\
\hline \multirow{4}{*}{$\begin{array}{c}\text { MOTIVI } \\
\text { POSTUPANJA } \\
\text { PREMA ŽIVOM } \\
\text { SVIJETU }\end{array}$} & Čovjekova je etička dužnost voditi brigu o životu životinja i biljaka & 4,09 & 0,772 \\
\hline & $\begin{array}{c}\text { Za život životinja i biljaka čovjek treba brinuti onoliko koliko ima od } \\
\text { njih koristi }\end{array}$ & 2,87 & 1,074 \\
\hline & Prema životu životinja i biljaka čovjek treba emotivno postupati & 3,75 & 0,893 \\
\hline & $\begin{array}{l}\text { Prema životinjama i biljkama čovjek se treba odnositi ovisno o } \\
\text { situaciji }\end{array}$ & 3,24 & 0,989 \\
\hline
\end{tabular}


Tablica 2.

Postoci odgovora za „pravo na život“ i „motive postupanja prema živom svijetu“ (\%)

\begin{tabular}{|c|c|c|c|c|}
\hline & TVRDNJE & $\begin{array}{c}\text { Uopće se ne } \\
\text { slažem + } \\
\text { Ne slažem se }\end{array}$ & $\begin{array}{l}\text { Slažem se i } \\
\text { ne slažem }\end{array}$ & \begin{tabular}{|c|} 
Slažem se + \\
U potpunosti \\
se slažem
\end{tabular} \\
\hline \multirow{3}{*}{$\begin{array}{l}\text { PRAVO ŽIVOG } \\
\text { SVIJJETA NA } \\
\text { ŽIVOT }\end{array}$} & $\begin{array}{c}\text { Svaka životinjska vrsta ima jednako pravo } \\
\text { na život kao i čovjek }\end{array}$ & 11,8 & 17,3 & 70,9 \\
\hline & $\begin{array}{l}\text { Čovjek ima veće pravo na život od } \\
\text { Životinjskih vrsta }\end{array}$ & 33,2 & 23,3 & 43,4 \\
\hline & $\begin{array}{l}\text { Svaka vrsta ima onoliko prava koliko izbori } \\
\text { u odnosu na druge vrste }\end{array}$ & 26,7 & 36,8 & 36,5 \\
\hline \multirow{4}{*}{$\begin{array}{c}\text { MOTIVI } \\
\text { POSTUPANJA } \\
\text { PREMA ŻIVOM } \\
\text { SVIJETU }\end{array}$} & $\begin{array}{c}\text { Čovjekova je etička dužnost voditi brigu o } \\
\text { životu životinja i biljaka }\end{array}$ & 3,0 & 15,7 & 81,3 \\
\hline & $\begin{array}{l}\text { Za život životinja i biljaka čovjek treba } \\
\text { brinuti onoliko koliko ima od njih koristi }\end{array}$ & 37,0 & 35,0 & 28,0 \\
\hline & $\begin{array}{c}\text { Prema životu životinja i biljaka čovjek } \\
\text { treba emotiono postupati }\end{array}$ & 7,4 & 28,7 & 63,9 \\
\hline & $\begin{array}{l}\text { Prema životinjama i biljkama čovjek se } \\
\text { treba odnositi ovisno o situaciji }\end{array}$ & 22,1 & 34,4 & 43,5 \\
\hline
\end{tabular}

U tablici 1. prikazane su aritmetičke sredine, a u tablici 2. (grupirani) postoci odgovora ispitanika, iz kojih možemo vidjeti općenito prihvaćanje, odnosno odbacivanje ispitanih tvrdnji za dvije ispitane dimenzije: „pravo živoga svijeta na život“ i „motivi čovjekova postupanja prema živome svijetu“.

Kod „prava živoga svijeta na život“:

1. ispitanici se najviše slažu s tvrdnjom koja glasi „Svaka životinjska vrsta ima jednako pravo na život kao i čovjek" ( $\mathrm{M}=3,88 ; 70,9 \%)$

2. ispitanici su bliže sredini skale, ali s blagim pomakom rezultata prema slaganju oko tvrdnje "Čovjek ima veće pravo na život od životinjskih vrsta" ( $M=3,14$; $43,4 \%)$

3. ispitanici su najneodlučniji, ali i najviše podijeljeni oko tvrdnje „Svaka vrsta ima onoliko prava koliko izbori u odnosu na druge vrste" $(M=3,11)$.

Kod „motiva čovjekova postupanja prema živom svijetu“ veće su razlike u prosjecima između navedenih četiriju tvrdnji nego što je to između prethodno komentiranih tvrdnji za „prava na život“. Odnosno rezultati pokazuju sljedeće:

1. najviše ispitanika slaže se s tvrdnjom koja glasi „Čovjekova je etička dužnost voditi brigu o životu životinja i biljaka“ ( $\mathrm{M}=4,09 ; 81,3 \%)$

2. ispitanici se također u nešto manjoj mjeri slažu i s emotivnim postupanjem prema Živom svijetu $(\mathrm{M}=3,75 ; 63,9 \%)$.

3. Odgovori za sljedeće dvije tvrdnje bliži su sredini skale, s time da:

4. kod tvrdnje „Prema životinjama i biljkama čovjek se treba odnositi ovisno o situaciji" $(\mathrm{M}=3,24)$ naginju slaganju

5. kod tvrdnje „Za Život životinja i biljaka čovjek treba brinuti onoliko koliko ima od njih koristi" $(\mathrm{M}=2,87)$ naginju relativnom neslaganju. 


\subsection{Korelacije varijabli "pravo živog svijeta na život" $i$ "motivi čovjekova postupanja prema živom svijetu“}

Tablica 3.

Korelacije varijabli „pravo živog svijeta“ i „motivi postupanja prema živom svijetu“ (Pearson)

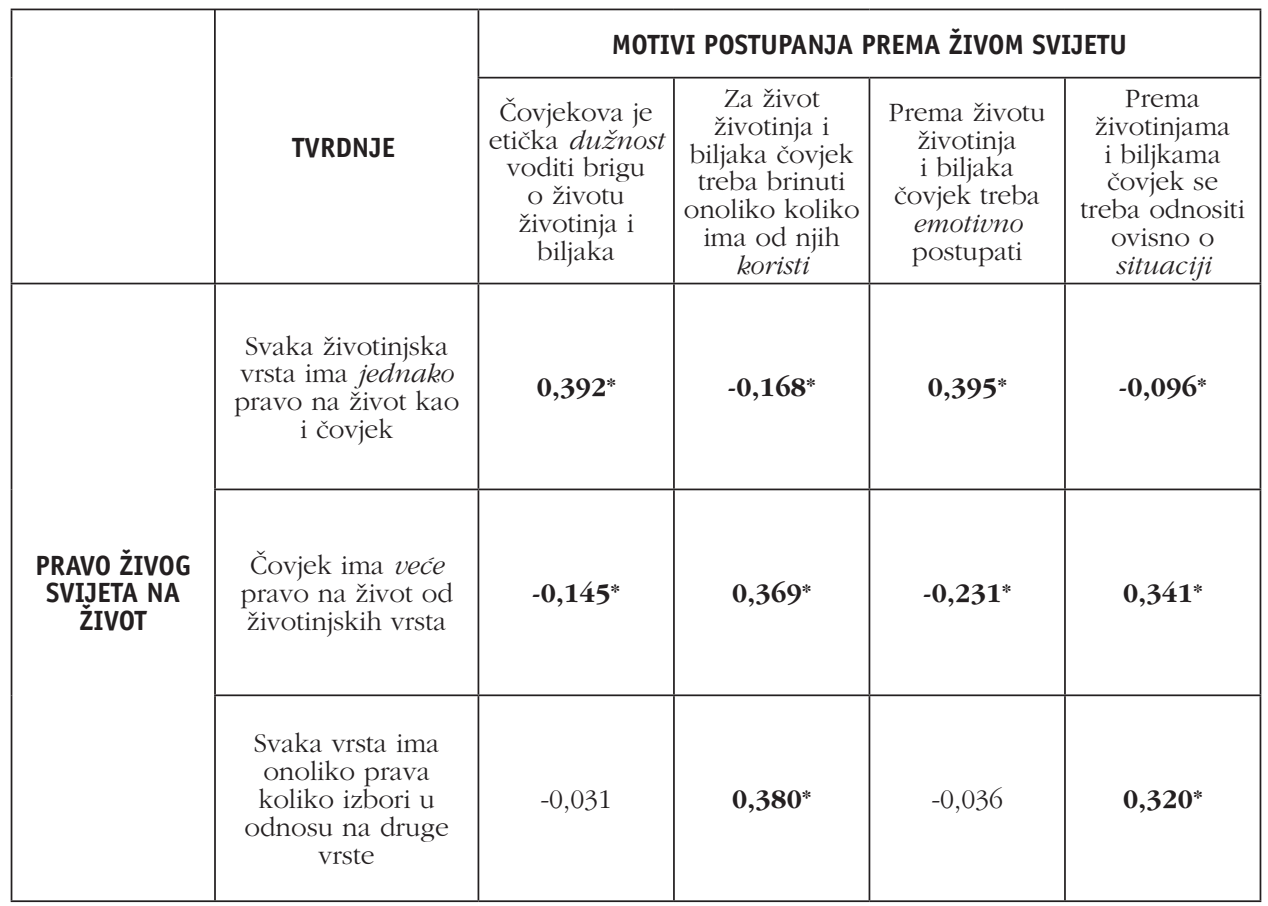

* Korelacije označene podebljano statistički su značajne ( $\mathrm{p}<0,001$; dvosmjerno testiranje).

Umjereno jake statistički značajne pozitivne korelacije pronalazimo između triju varijabli percepcije „prava živog svijeta na život“ i po dvije etičke „motivacije čovjekova postupanja prema živom svijetu“:

1. između jednakog prava na život svih živih bića i dužnosti $(r=0,392, p<0,001)$ te emotivnosti u čovjekovu postupanju prema živom svijetu $(r=0,40, p<0,001)$

2. između većeg prava čovjeka na život i utilitarnog $(r=0,37, p<0,001)$ te situacijskog $(r=0,34, p<0,001)$ čovjekova postupanja prema živom svijetu

3. između izborenog prava živog svijeta i utilitarnog $(r=0,38, p<0,001)$ te situacijskog $(r=0,32, p<0,001)$ čovjekova postupanja prema živom svijetu.

Statistički značajne, no vrlo slabe negativne korelacije pronađene su:

1. između jednakog prava na život svih živih bića i utilitarnog $(r=-0,17, p<0,001)$ te situacijskog $(r=-0,10, p<0,001)$ čovjekova postupanja prema živom svijetu

2. između većeg prava čovjeka na život i dužnosti $(r=-0,15, p>0,001)$ te emotivnosti u čovjekovu postupanju prema živom svijetu $(\mathrm{r}=-0,23, \mathrm{p}<0,001)$. 


\subsection{Opće distribucije i razlike u prosjecima rezultata za "pravo živog svijeta na život" $i$ "motive čovjekova postupanja prema živom svijetu" $s$ obzirom na sociodemografska obilježja}

Tablica 4a.

Prosječne razlike „prava na život“ i „motiva postupanja prema živom svijetu“ s obzirom na spol (M)

\begin{tabular}{|c|c|c|c|}
\hline & \multirow{2}{*}{ TVRDNJE } & \multicolumn{2}{|c|}{ spol (M) } \\
\hline & & m & $\check{z}$ \\
\hline \multirow{3}{*}{$\begin{array}{l}\text { PRAVO ŽIVOG } \\
\text { SVIJETA NA ŽIVOT }\end{array}$} & $\begin{array}{c}\text { Svaka životinjska vrsta ima jednako pravo na život } \\
\text { kao i čovjek }\end{array}$ & 3,78 & 3,97 \\
\hline & Čovjek ima veće pravo na život od životinjskih vrsta & 3,25 & 3,04 \\
\hline & $\begin{array}{l}\text { Svaka vrsta ima onoliko prava koliko izbori u odnosu } \\
\text { na druge vrste }\end{array}$ & 3,17 & 3,06 \\
\hline \multirow{4}{*}{$\begin{array}{c}\text { MOTIVI } \\
\text { POSTUPANJA } \\
\text { PREMA ŽIVOM } \\
\text { SVIJETU }\end{array}$} & $\begin{array}{c}\text { Čovjekova je etička dužnost voditi brigu o životu } \\
\text { životinja i biljaka }\end{array}$ & 4,01 & 4,16 \\
\hline & $\begin{array}{l}\text { Za život životinja i biljaka čovjek treba brinuti } \\
\text { onoliko koliko ima od njih koristi }\end{array}$ & 2,98 & 2,76 \\
\hline & $\begin{array}{c}\text { Prema životu životinja i biljaka čovjek treba emotivno } \\
\text { postupati }\end{array}$ & 3,61 & 3,87 \\
\hline & $\begin{array}{c}\text { Prema životinjama i biljkama čovjek se treba odnositi } \\
\text { ovisno o situaciji }\end{array}$ & 3,33 & 3,16 \\
\hline
\end{tabular}

Iz aritmetičkih sredina „prava živog svijeta na život“ može se vidjeti da se ispitanice u prosjeku nešto više slažu s tvrdnjom „Svaka životinjska vrsta ima jednako pravo na život kao i čovjek" ( $\mathrm{M}=3,97)$. Ispitanici su prosječno nešto skloniji tvrdnjama „Čovjek ima veće pravo na život od životinjskih vrsta“ $(M=3,25)$ i „Svaka vrsta ima onoliko prava koliko izbori u odnosu na druge vrste“ $(M=3,17)$.

Kod „motiva postupanja prema živom svijetu“ ispitanici su prosječno skloniji tvrdnji „Prema životinjama i biljkama čovjek se treba odnositi ovisno o situaciji“ $(\mathrm{M}=3,33)$ i „Za život životinja i biljaka čovjek treba brinuti onoliko koliko ima od njih koristi" $(\mathrm{M}=2,98)$. Ispitanice nešto više od ispitanika preferiraju čovjekovu dužnost $(\mathrm{M}=$ $4,16)$ i emotivnost $(M=3,87)$ kao motive čovjekove brige za život oko sebe. 
Tablica 4b.

Razlike u prosjecima „prava na život“ i „motiva postupanja prema živom svijetu“ i spola (t-test)

\begin{tabular}{|c|c|c|c|c|c|c|c|}
\hline & \multirow{2}{*}{ TVRDNJE } & \multirow{2}{*}{+} & \multirow{2}{*}{ 生 } & \multirow{2}{*}{ 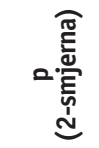 } & \multicolumn{2}{|c|}{$\Sigma$} & \multirow{2}{*}{$\frac{v}{\wedge}$} \\
\hline & & & & & $\Xi$ & iN & \\
\hline \multirow{2}{*}{$\begin{array}{l}\text { PRAVO ŽIVOG } \\
\text { SVIJETA NA } \\
\text { ŽIVOT }\end{array}$} & $\begin{array}{l}\text { Svaka Životinjska vrsta } \\
\text { ima jednako pravo na } \\
\text { život kao i čovjek }\end{array}$ & $-2,952$ & 980,647 & 0,003 & 3,78 & 3,97 & $\check{z}>m$ \\
\hline & $\begin{array}{c}\text { Čovjek ima veće pravo } \\
\text { na život od životinjskih } \\
\text { vrsta }\end{array}$ & 2,613 & 998 & 0,009 & 3,25 & 3,04 & $\mathrm{~m}>\check{z}$ \\
\hline \multirow{4}{*}{$\begin{array}{l}\text { MOTIVI } \\
\text { POSTUPANJA } \\
\text { PREMA ŽIVOM } \\
\text { SVIJETU }\end{array}$} & $\begin{array}{c}\text { Čovjekova je etička } \\
\text { dužnost voditi brigu o } \\
\text { životu životinja i biljaka }\end{array}$ & $-3,065$ & 998 & 0,002 & 4,01 & 4,16 & $\check{z}>m$ \\
\hline & $\begin{array}{l}\text { Za život životinja i } \\
\text { biljaka čovjek treba } \\
\text { brinuti onoliko koliko } \\
\text { ima od njih koristi }\end{array}$ & 3,336 & 994,782 & 0,001 & 2,98 & 2,76 & $\mathrm{~m}>\check{z}$ \\
\hline & $\begin{array}{l}\text { Prema životu životinja } \\
\text { i biljaka čovjek treba } \\
\text { emotivno postupati }\end{array}$ & $-4,752$ & 956,397 & $>0,001$ & 3,61 & 3,87 & $\check{z}>\mathrm{m}$ \\
\hline & $\begin{array}{c}\text { Prema životinjama i } \\
\text { biljkama čovjek se } \\
\text { treba odnositi ovisno o } \\
\text { situaciji }\end{array}$ & 2,679 & 998 & 0,008 & 3,33 & 3,16 & $\mathrm{~m}>\check{z}$ \\
\hline
\end{tabular}

Rezultati provedenog t-testa potvrđuju ono na što navedene opće distribucije ukazuju. Za „pravo živog svijeta na život":

1. žene statistički značajno više preferiraju jednakost prava na život u odnosu na muškarce

2. muškarci statistički značajno više preferiraju veće pravo čovjeka na život u odnosu na žene.

Za treću tvrdnju „Svaka vrsta ima onoliko prava koliko izbori u odnosu na druge vrste" nema statistički značajne razlike u percepciji između muškaraca i žena.

Kod „motiva čovjekova postupanja prema živom svijetu“:

1. Žene statistički značajno više preferiraju dužnost i emotivnost u motivima čovjekova postupanja prema živom svijetu u odnosu na muškarce

2. muškarci statistički značajno više preferiraju korisnost i situacijsku motivaciju čovjekova postupanja prema živom svijetu u odnosu na žene. 
Tablica 5a.

Prosječne razlike „prava na život“ i „motiva postupanja prema živom svijetu“ s obzirom na dob (M)

\begin{tabular}{|c|c|c|c|c|}
\hline & TVRDNJE & dob & $\mathrm{N}$ & $M$ \\
\hline \multirow{18}{*}{$\begin{array}{c}\text { PRAVO ŽIVOG SVIJETA } \\
\text { NA ŽIVOT }\end{array}$} & \multirow{6}{*}{$\begin{array}{c}\text { Svaka životinjska vrsta ima jednako pravo } \\
\text { na život kao i čovjek }\end{array}$} & $15-24$ & 138 & 3,80 \\
\hline & & $25-34$ & 159 & 3,93 \\
\hline & & $35-44$ & 156 & 3,72 \\
\hline & & $45-54$ & 171 & 3,87 \\
\hline & & $55-64$ & 163 & 3,99 \\
\hline & & $65+$ & 213 & 3,94 \\
\hline & \multirow{6}{*}{$\begin{array}{c}\text { Čovjek ima veće pravo na život od } \\
\text { životinjskih vrsta }\end{array}$} & $15-24$ & 138 & 3,08 \\
\hline & & $25-34$ & 159 & 2,87 \\
\hline & & $35-44$ & 156 & 3,09 \\
\hline & & $45-54$ & 171 & 3,18 \\
\hline & & $55-64$ & 163 & 3,19 \\
\hline & & $65+$ & 213 & 3,33 \\
\hline & \multirow{6}{*}{$\begin{array}{l}\text { Svaka vrsta ima onoliko prava koliko } \\
\text { izbori u odnosu na druge vrste }\end{array}$} & $15-24$ & 138 & 3,06 \\
\hline & & $25-34$ & 159 & 2,97 \\
\hline & & $35-44$ & 156 & 3,03 \\
\hline & & $45-54$ & 171 & 3,07 \\
\hline & & $55-64$ & 163 & 3,21 \\
\hline & & $65+$ & 213 & 3,27 \\
\hline \multirow{24}{*}{$\begin{array}{l}\text { MOTIVI POSTUPANJA } \\
\text { PREMA ŽIVOM SVIJETU }\end{array}$} & \multirow{6}{*}{$\begin{array}{c}\text { Čovjekova je etička dužnost voditi brigu o } \\
\text { životu životinja i biljaka }\end{array}$} & $15-24$ & 138 & 4,09 \\
\hline & & $25-34$ & 159 & 4,05 \\
\hline & & $35-44$ & 156 & 4,07 \\
\hline & & $45-54$ & 171 & 4,11 \\
\hline & & $55-64$ & 163 & 4,09 \\
\hline & & $65+$ & 213 & 4,10 \\
\hline & \multirow{6}{*}{$\begin{array}{l}\text { Za život životinja i biljaka čovjek treba } \\
\text { brinuti onoliko koliko ima od njih koristi }\end{array}$} & $15-24$ & 138 & 2,79 \\
\hline & & $25-34$ & 159 & 2,78 \\
\hline & & $35-44$ & 156 & 2,84 \\
\hline & & $45-54$ & 171 & 2,79 \\
\hline & & $55-64$ & 163 & 2,84 \\
\hline & & $65+$ & 213 & 3,08 \\
\hline & \multirow{6}{*}{$\begin{array}{c}\text { Prema životu životinja i biljaka čovjek } \\
\text { treba emotivno postupati }\end{array}$} & $15-24$ & 138 & 3,77 \\
\hline & & $25-34$ & 159 & 3,81 \\
\hline & & $35-44$ & 156 & 3,71 \\
\hline & & $45-54$ & 171 & 3,72 \\
\hline & & $55-64$ & 163 & 3,77 \\
\hline & & $65+$ & 213 & 3,71 \\
\hline & \multirow{6}{*}{$\begin{array}{l}\text { Prema životinjama i biljkama čovjek se } \\
\text { treba odnositi ovisno o situaciji }\end{array}$} & $15-24$ & 138 & 3,21 \\
\hline & & $25-34$ & 159 & 3,11 \\
\hline & & $35-44$ & 156 & 3,18 \\
\hline & & $45-54$ & 171 & 3,34 \\
\hline & & $55-64$ & 163 & 3,18 \\
\hline & & $65+$ & 213 & 3,36 \\
\hline
\end{tabular}


Aritmetičke sredine „prava živog svijeta na život“ ukazuju na to da svi ispitanici neovisno o dobi naginju slaganju s tvrdnjom o jednakosti živog svijeta. Slično se i kod izborenog prava odgovori većinom nalaze blizu sredine ljestvice, s time da stariji $(65+)$ u odnosu na mlađe ispitanike (25 - 34) pokazuju blagu naklonost. Kod tvrdnje o čovjekovu većem pravu nešto joj se skloniji čine stariji ispitanici ( 45 godine i više).

Kod „motiva postupanja prema živom svijetu“ ponovno nema velikih odstupanja od slaganja s čovjekovom dužnosti s obzirom na dob ispitanika. Čini se da su stariji ispitanici $(65+)$ nešto skloniji tvrdnjama vezanima za korisnost $(M=3,08)$ i situaciju $(\mathrm{M}=3,36)$, a mlađi ispitanici emotivnosti $(\mathrm{M}=3,81)$ kao motivu čovjekove brige za život oko sebe.

Tablica 5b.

Razlike u prosjecima „prava na život“ i „motiva postupanja prema živom svijetu“ i dobi (ANOVA)

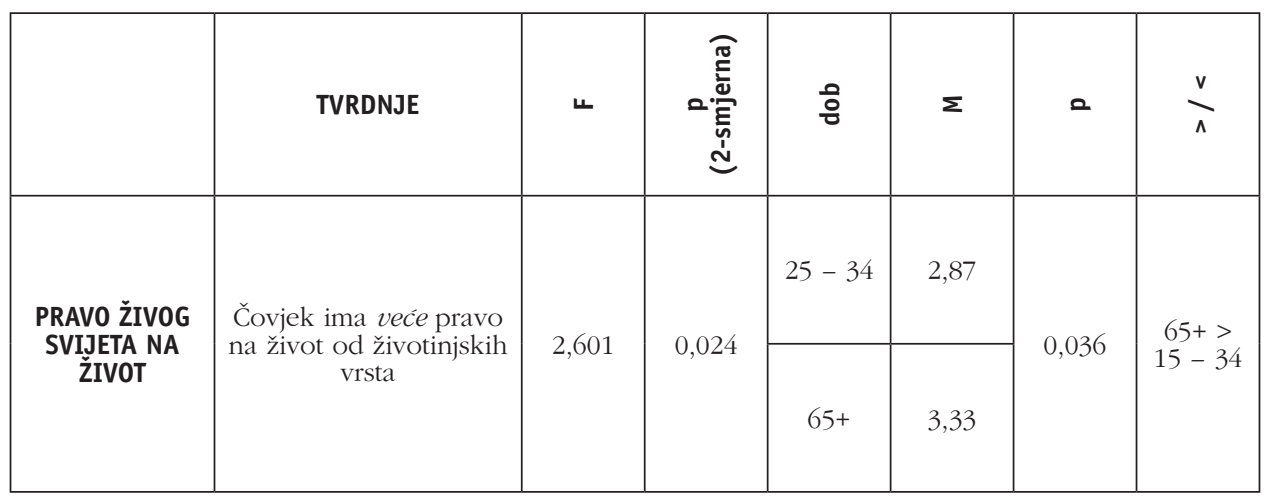

* Proveden je Scheffeov post-hoc test na $\mathrm{p}=0,05$.

Statistički značajni rezultati analize varijance pokazali su se jedino za prvu ispitanu dimenziju „prava na život“, te pokazuju da su građani/ke od 65 godina i stariji skloniji tvrdnji da čovjek ima veće pravo na život od građana/ki između 25 i 34 godina.

Nisu pronađene statistički značajne razlike za jednakost čovjeka i ostalog živog svijeta te izboreno pravo kao ni cijelu drugu dimenziju motiva postupanja prema živom svijetu s obzirom na dob. 
Tablica 6a.

Prosječne razlike „prava na život“ i ,motiva postupanja prema živom svijetu“ s obzirom na veličinu naselja (M)

\begin{tabular}{|c|c|c|c|c|}
\hline & TVRDNJE & veličina naselja & $\mathrm{N}$ & $M$ \\
\hline \multirow{12}{*}{$\begin{array}{l}\text { PRAVO ŽIVOG } \\
\text { SVIJETA NA } \\
\text { ŽIVOT }\end{array}$} & \multirow{4}{*}{$\begin{array}{c}\text { Svaka Životinjska } \\
\text { vrsta ima jednako } \\
\text { pravo na život kao i } \\
\text { čovjek }\end{array}$} & do 2000 & 388 & 3,94 \\
\hline & & $2001-10.000$ & 161 & 3,97 \\
\hline & & $10.001-100.000$ & 218 & 3,78 \\
\hline & & $100.000+$ & 232 & 3,82 \\
\hline & \multirow{4}{*}{$\begin{array}{l}\text { Čovjek ima veće } \\
\text { pravo na život od } \\
\text { životinjskih vrsta }\end{array}$} & do 2000 & 388 & 3,36 \\
\hline & & $2001-10.000$ & 161 & 3,23 \\
\hline & & $10.001-100.000$ & 218 & 2,98 \\
\hline & & $100.000+$ & 232 & 2,84 \\
\hline & \multirow{4}{*}{$\begin{array}{c}\text { Svaka vrsta ima } \\
\text { onoliko prava koliko } \\
\text { izbori u odnosu na } \\
\text { druge vrste }\end{array}$} & do 2000 & 388 & 3,20 \\
\hline & & $2001-10.000$ & 161 & 3,15 \\
\hline & & $10.001-100.000$ & 218 & 3,09 \\
\hline & & $100.000+$ & 232 & 2,95 \\
\hline \multirow{16}{*}{$\begin{array}{l}\text { MOTIVI } \\
\text { POSTUPANJA } \\
\text { PREMA ŽIVOM } \\
\text { SVIJETU }\end{array}$} & \multirow{4}{*}{$\begin{array}{c}\text { Čovjekova je etička } \\
\text { dužnost voditi brigu } \\
\text { o životu životinja i } \\
\text { biljaka }\end{array}$} & do 2000 & 388 & 4,12 \\
\hline & & $2001-10.000$ & 161 & 4,05 \\
\hline & & $10.001-100.000$ & 218 & 4,01 \\
\hline & & $100.000+$ & 232 & 4,14 \\
\hline & \multirow{4}{*}{$\begin{array}{c}\text { Za život životinja i } \\
\text { biljaka čovjek treba } \\
\text { brinuti onoliko koliko } \\
\text { ima od njih koristi }\end{array}$} & do 2000 & 388 & 2,93 \\
\hline & & 2001-10.000 & 161 & 3,05 \\
\hline & & $10.001-100.000$ & 218 & 2,84 \\
\hline & & $100.000+$ & 232 & 2,65 \\
\hline & \multirow{4}{*}{$\begin{array}{c}\text { Prema životu životinja } \\
\text { i biljaka čovjek treba } \\
\text { emotivno postupati }\end{array}$} & do 2000 & 388 & 3,72 \\
\hline & & $2001-10.000$ & 161 & 3,84 \\
\hline & & $10.001-100.000$ & 218 & 3,68 \\
\hline & & $100.000+$ & 232 & 3,78 \\
\hline & \multirow{4}{*}{$\begin{array}{l}\text { Prema životinjama i } \\
\text { bilikama čovjek se } \\
\text { treba odnositi ovisno } \\
\text { o situaciji }\end{array}$} & do 2000 & 388 & 3,34 \\
\hline & & $2001-10.000$ & 161 & 3,46 \\
\hline & & $10.001-100.000$ & 218 & 3,19 \\
\hline & & $100.000+$ & 232 & 2,97 \\
\hline
\end{tabular}

Iz aritmetičkih sredina možemo vidjeti da ispitanici iz manjih naselja veličine do 2000 stanovnika imaju najviše prosjeke na tvrdnjama o čovjekovom većem pravu na Život $(M=3,36)$ i borbi vrsta za opstanak $(M=3,20)$. Što su veća naselja i gradovi to je manje slaganje s tim tvrdnjama. S čovjekovim većim pravom na život ne slažu se ispitanici iz gradova od 10.000 do preko 100.000 stanovnika, a s borbom za opstanak najviše se ne slažu ispitanici iz naselja iznad 100.000 stanovnika, odnosno grada Zagreba. S obzirom na „prava živih bića na život“, za tvrdnju o jednakosti prava na Život ispitanici iz naselja svih veličina (ruralno i urbano stanovništvo) stoje na sredini skale s malim naklonom prema slaganju. Ispitanici iz manjih gradova veličine 2001 - 10.000 stanovnika imaju najviši prosjek $(M=3,97)$, zatim blisko slijede ispitanici iz manjih naselja veličine do 2000 stanovnika pa gradovi od 10.000 do 100.000 stanovnika i više.

Kod „motiva čovjekova postupanja prema živom svijetu“ razlike nalazimo kod tvrdnje vezane za situaciju, kojoj su nešto skloniji ispitanici iz manjih naselja (do 10.000 stanovnika), a neskloniji ispitanici iz najvećeg grada Zagreba te za korist, kojoj su 
također nešto skloniji ispitanici iz manjih gradova (2000 - 10.000), na sredini skale ispitanici su iz naselja do 2000 stanovnika, a naklon prema neslaganju pronalazimo kod ispitanika iz većih naselja. Ispitanici iz naselja svih veličina (ruralno i urbano stanovništvo) skloni su tvrdnji vezanoj za dužnost, a nisu neskloni ni emotivnosti.

Tablica $6 b$.

Razlike u prosjecima „prava na život“ i „motiva postupanja prema živom svijetu“ i veličine naselja (ANOVA)

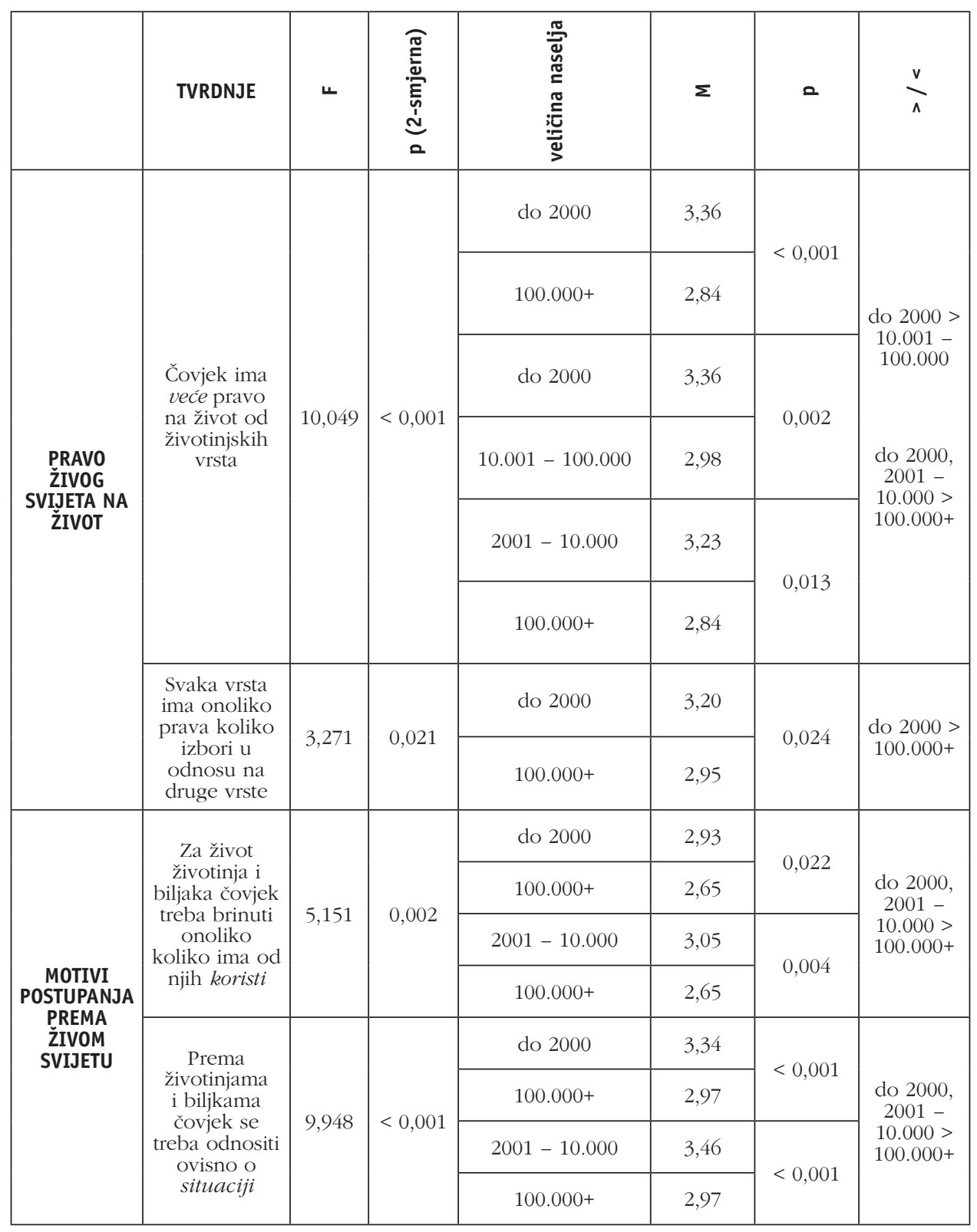

* Provedeni su Scheffeov i Tamhaneov T2 post-hoc testovi na $\mathrm{p}=0,05$. 
Rezultati ANOVA-e pokazuju sljedeće za „pravo živog svijeta na život“:

1. građani/ke iz mjesta do 2000 stanovnika statistički značajno više preferiraju čovjekovo veće pravo na život od ostalih živih bića u odnosu na one iz gradova od 10.000 do preko 100.000 stanovnika (10.000 - 100.000 i 100.000+). Dodatno, građani/ke iz mjesta između 2001 i 10.000 stanovnika statistički značajno više preferiraju čovjekovo veće pravo na život od ostalih živih bića u odnosu na one iz grada preko 100.000 stanovnika

2. građani/ke iz mjesta do 2000 stanovnika statistički značajno više preferiraju to da vrste imaju onoliko prava koliko izbore u odnosu na one iz grada preko 100.000 stanovnika.

Nisu pronađene statistički značajne razlike za jednakost čovjeka i ostalog živog svijeta s obzirom na veličinu naselja.

Rezultati pokazuju sljedeće za „motive postupanja prema živom svijetu“:

1. građani/ke iz grada preko 100.000 stanovnika statistički značajno manje preferiraju korisnost kao motivaciju čovjekova postupanja prema živom svijetu u odnosu na one iz mjesta do 10.000 stanovnika (do 2000 i 2001 - 10.000 stanovnika)

2. građani/ke koji dolaze iz grada preko 100.000 stanovnika statistički značajno manje preferiraju situacijsku etiku kao motivaciju čovjekova postupanja prema živom svijetu u odnosu na one iz mjesta do 10.000 stanovnika (do 2000 i 2001 - 10.000 stanovnika).

Nisu pronađene statistički značajne razlike kod dužnosti i emotivnosti kao motiva čovjekova postupanja prema živom svijetu s obzirom na veličinu naselja.

Tablica 7a.

Prosječne razlike „prava na život“ i „motiva postupanja prema živom svijetu“ s obzirom na regije (M)

\begin{tabular}{|c|c|c|c|c|}
\hline & TVRDNJE & regija & $\mathrm{N}$ & $M$ \\
\hline \multirow{18}{*}{$\begin{array}{c}\text { PRAVO ŽIVOG SVIJETA } \\
\text { NA ŽIVOT }\end{array}$} & \multirow{6}{*}{$\begin{array}{c}\text { Svaka životinjska } \\
\text { vrsta ima jednako } \\
\text { pravo na život kao i } \\
\text { čovjek }\end{array}$} & Zagreb i okolica & 258 & 3,88 \\
\hline & & Sjeverna Hrvatska & 172 & 3,93 \\
\hline & & Slavonija & 167 & 3,77 \\
\hline & & Lika, Kordun, Banovina & 83 & 4,00 \\
\hline & & Istra, Primorje, Gorski kotar & 121 & 4,03 \\
\hline & & Dalmacija & 199 & 3,79 \\
\hline & \multirow{6}{*}{$\begin{array}{l}\text { Čovjek ima veće } \\
\text { pravo na život od } \\
\text { životinjskih vrsta }\end{array}$} & Zagreb i okolica & 258 & 2,80 \\
\hline & & Sjeverna Hrvatska & 172 & 3,15 \\
\hline & & Slavonija & 167 & 3,34 \\
\hline & & Lika, Kordun, Banovina & 83 & 3,90 \\
\hline & & Istra, Primorje, Gorski kotar & 121 & 2,65 \\
\hline & & Dalmacija & 199 & 3,37 \\
\hline & \multirow{6}{*}{$\begin{array}{c}\text { Svaka vrsta ima } \\
\text { onoliko prava koliko } \\
\text { izbori u odnosu na } \\
\text { druge vrste }\end{array}$} & Zagreb i okolica & 258 & 3,00 \\
\hline & & Sjeverna Hrvatska & 172 & 3,04 \\
\hline & & Slavonija & 167 & 3,11 \\
\hline & & Lika, Kordun, Banovina & 83 & 3,58 \\
\hline & & Istra, Primorje, Gorski kotar & 121 & 3,03 \\
\hline & & Dalmacija & 199 & 3,16 \\
\hline
\end{tabular}




\begin{tabular}{|c|c|c|c|c|}
\hline & TVRDNJE & regija & $\mathrm{N}$ & M \\
\hline \multirow{24}{*}{$\begin{array}{l}\text { MOTIVI POSTUPANJA } \\
\text { PREMA ŽIVOM SVIJETU }\end{array}$} & \multirow{6}{*}{$\begin{array}{l}\text { Čovjekova je etička } \\
\text { dužnost voditi brigu } \\
\text { o životu životinja i } \\
\text { biljaka }\end{array}$} & Zagreb i okolica & 258 & 4,12 \\
\hline & & Sjeverna Hrvatska & 172 & 4,02 \\
\hline & & Slavonija & 167 & 4,13 \\
\hline & & Lika, Kordun, Banovina & 83 & 4,16 \\
\hline & & Istra, Primorje, Gorski kotar & 121 & 4,05 \\
\hline & & Dalmacija & 199 & 4,06 \\
\hline & \multirow{6}{*}{$\begin{array}{l}\text { Za život životinja i } \\
\text { biljaka čovjek treba } \\
\text { brinuti onoliko koliko } \\
\text { ima od njih koristi }\end{array}$} & Zagreb i okolica & 258 & 2,70 \\
\hline & & Sjeverna Hrvatska & 172 & 2,83 \\
\hline & & Slavonija & 167 & 2,91 \\
\hline & & Lika, Kordun, Banovina & 83 & 3,29 \\
\hline & & Istra, Primorje, Gorski kotar & 121 & 2,76 \\
\hline & & Dalmacija & 199 & 2,96 \\
\hline & \multirow{6}{*}{$\begin{array}{l}\text { Prema životu životinja } \\
\text { i biljaka čovjek treba } \\
\text { emotivno postupati }\end{array}$} & Zagreb i okolica & 258 & 3,75 \\
\hline & & Sjeverna Hrvatska & 172 & 3,90 \\
\hline & & Slavonija & 167 & 3,70 \\
\hline & & Lika, Kordun, Banovina & 83 & 3,62 \\
\hline & & Istra, Primorje, Gorski kotar & 121 & 3,61 \\
\hline & & Dalmacija & 199 & 3,79 \\
\hline & \multirow{6}{*}{$\begin{array}{l}\text { Prema životinjama i } \\
\text { biljkama čovjek se } \\
\text { treba odnositi ovisno } \\
\text { o situaciji }\end{array}$} & Zagreb i okolica & 258 & 2,97 \\
\hline & & Sjeverna Hrvatska & 172 & 3,28 \\
\hline & & Slavonija & 167 & 3,42 \\
\hline & & Lika, Kordun, Banovina & 83 & 3,52 \\
\hline & & Istra, Primorje, Gorski kotar & 121 & 3,10 \\
\hline & & Dalmacija & 199 & 3,36 \\
\hline
\end{tabular}

Iz aritmetičkih sredina možemo vidjeti da ispitanici iz Like, Korduna i Banovine iskazuju najveće slaganje $s$ tvrdnjom vezanom uz čovjekovo veće pravo na život ( $M$ =3,90). Slijede ispitanici iz Dalmacije pa Slavonije i Sjeverne Hrvatske, a nešto veći naklon prema neslaganju iskazuju ispitanici iz Zagreba, a najviše Istre te Primorja i Gorskog kotara. Ispitanici iz Like, Korduna i Banovine iskazuju i najveće slaganje s tvrdnjom o izborenom pravu $(M=3,58)$. Slijede ispitanici iz Dalmacije pa Slavonije, a zatim na sredini skale Sjeverne Hrvatske, Istre, Primorja i Gorskog kotara pa Zagreba. Konačno, ispitanici iz Istre, Primorja i Gorskog kotara iskazali su najveće preferiranje jednakosti prava svake vrste na život $(M=4,03)$, ali blisko slijede i ispitanici iz Like, Korduna i Banovine te Sjeverne Hrvatske i Zagreba, pa Dalmacije i Slavonije.

Kod „motiva čovjekova postupanja prema živom svijetu“, ispitanike iz Like, Korduna i Banovine najviše motivira dužnost $(M=4,16)$, a iza njih slijede i ispitanici iz Slavonije, Zagreba, Dalmacije, Istre, Primorja i Gorskog kotara te Sjeverne Hrvatske. Ispitanike iz Like, Korduna i Banovine najviše motivira i situacija $(M=3,52)$, a slijede ispitanici iz Slavonije, Dalmacije, Sjeverne Hrvatske pa Istre, Primorja i Gorskog kotara, a naklon prema neslaganju iskazuju ispitanici iz Zagreba. Konačno, i za korisnost kao motiv postupanja najviše su ispitanici iz Like, Korduna i Banovine (M $=3,29$ ), dok ispitanici iz ostalih regija iskazuju naklon prema neslaganju, i to (od najmanjeg neslaganja ka najvišem) oni iz Dalmacije, Slavonije, Sjeverne Hrvatske, Istre, Primorja i Gorskog kotara te Zagreba. S emotivnosti kao motivom postupanja čovjeka prema živom svijetu najviše se slažu ispitanici iz Sjeverne Hrvatske $(M=$ 3,90), a slijede oni iz Dalmacije, Zagreba, Slavonije, Like, Korduna i Banovine te Istre, Primorja i Gorskog kotara. 


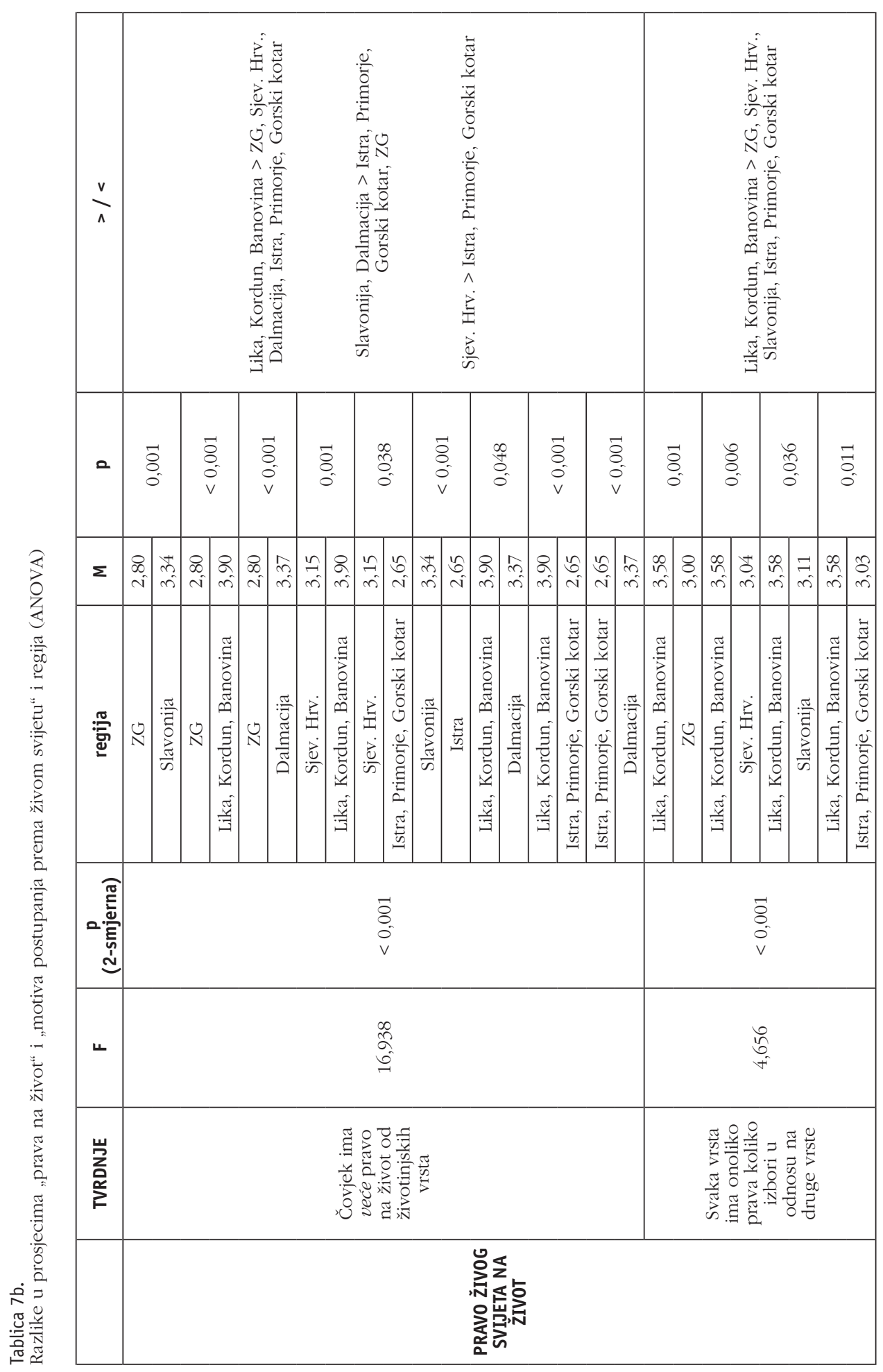




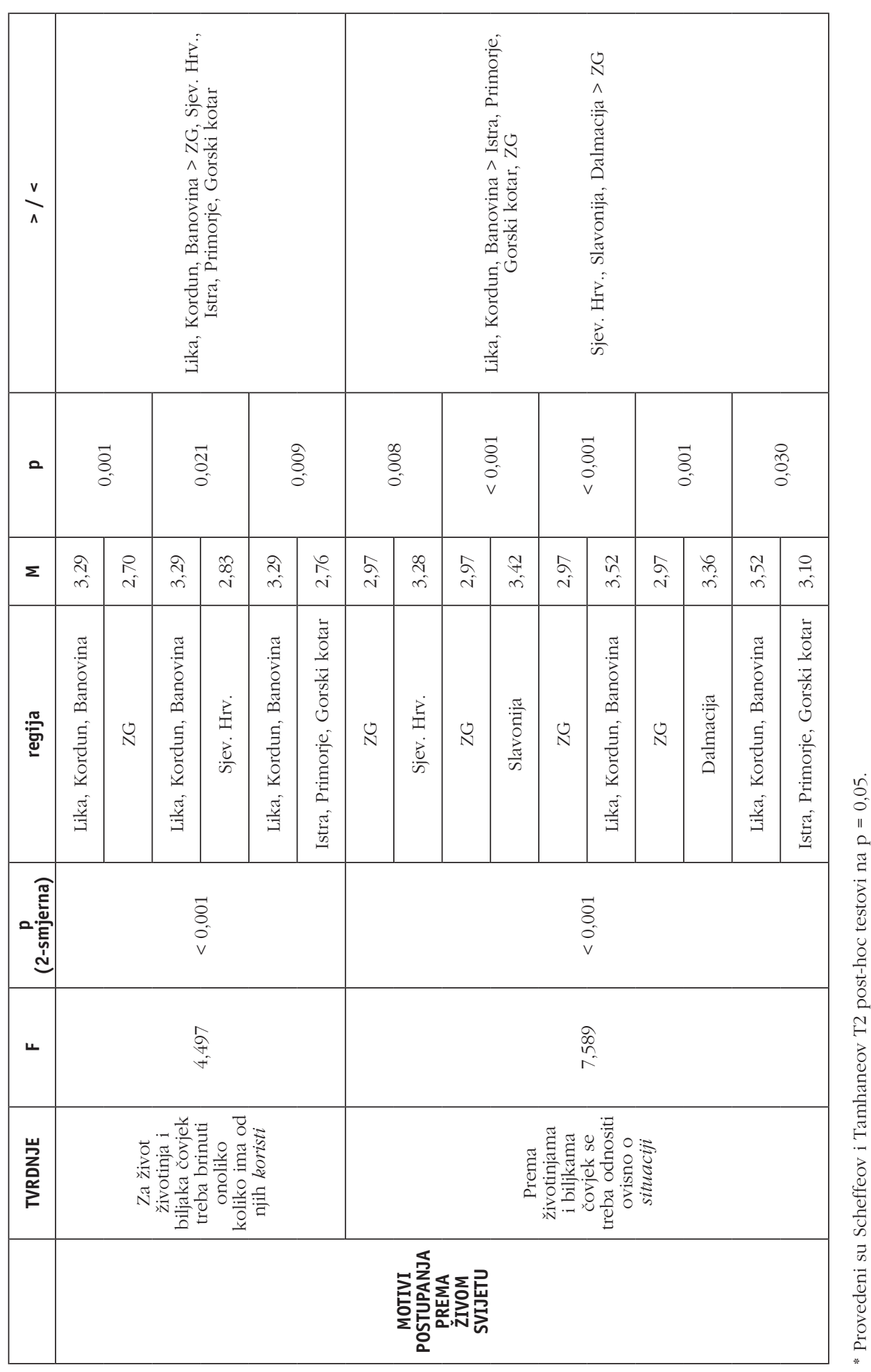


Rezultati ANOVA-e pokazuju sljedeće za „pravo živog svijeta na život“:

1. građani/ke iz Like, Korduna i Banovine statistički značajno više preferiraju čovjekovo veće pravo na život od ostalih živih bića u odnosu na one iz Zagreba, Sjeverne Hrvatske, Dalmacije te Istre, Primorja i Gorskog kotara. Nadalje, građani/ke iz Istre, Primorja i Gorskog kotara i Zagreba statistički značajno manje preferiraju čovjekovo veće pravo na život od ostalih živih bića u odnosu na one iz Slavonije i Dalmacije, a Istra, Primorje i Gorski kotar i u odnosu na građane/ ke iz Sjeverne Hrvatske

2. 2) građani/ke iz Like, Korduna i Banovine statistički značajno više preferiraju da vrste imaju onoliko prava koliko izbore u odnosu na one iz Zagreba, Sjeverne Hrvatske, Slavonije te Istre, Primorja i Gorskog kotara.

Nisu pronađene statistički značajne razlike za jednakost čovjeka i ostalog živog svijeta s obzirom na regionalnu pripadnost.

Za „motive postupanja prema živom svijetu“ rezultati statističkog testiranja pokazuju sljedeće:

1. građani/ke iz Like, Korduna i Banovine statistički značajno više preferiraju korisnost kao motivaciju čovjekova postupanja prema živom svijetu u odnosu na one iz Zagreba, Sjeverne Hrvatske te Istre, Primorja i Gorskog kotara

2. građani/ke iz Like, Korduna i Banovine statistički značajno više preferiraju situacijsku etiku kao motivaciju čovjekova postupanja prema živom svijetu u odnosu na one iz Istre, Primorja i Gorskog kotara. Građani/ke iz Zagreba statistički značajno manje preferiraju situacijsku etiku kao motivaciju čovjekova postupanja prema živom svijetu u odnosu na one iz Sjeverne Hrvatske, Slavonije, Dalmacije te Like, Korduna i Banovine.

Nisu pronađene statistički značajne razlike kod dužnosti i emotivnosti kao motiva čovjekova postupanja prema živom svijetu s obzirom na regionalnu pripadnost. 
Tablica 8a.

Prosječne razlike „prava na život“ i „motiva postupanja prema živom svijetu“ s obzirom na obrazovanje (M)

\begin{tabular}{|c|c|c|c|c|}
\hline & TVRDNJE & obrazovanje & $\mathrm{N}$ & M \\
\hline \multirow{21}{*}{$\begin{array}{l}\text { PRAVO ŽIVOG } \\
\text { SVIJETA NA } \\
\text { ŽIVOT }\end{array}$} & \multirow{7}{*}{$\begin{array}{c}\text { Svaka životinjska } \\
\text { vrsta ima jednako } \\
\text { pravo na život kao } \\
\text { i čovjek }\end{array}$} & nezavršena osnovna škola & 40 & 4,19 \\
\hline & & završena osnovna škola & 133 & 3,77 \\
\hline & & završena srednja škola 3 god. & 207 & 3,87 \\
\hline & & završena srednja škola 4 god. & 441 & 3,91 \\
\hline & & VŠS (viša i dodiplomski studij) & 94 & 3,86 \\
\hline & & završen fakultet (dipl. studij) & 81 & 3,76 \\
\hline & & poslijedipl. studij (magisterij, doktorat) & 3 & 4,26 \\
\hline & \multirow{7}{*}{$\begin{array}{l}\text { Čovjek ima veće } \\
\text { pravo na život od } \\
\text { životinjskih vrsta }\end{array}$} & nezavršena osnovna škola & 40 & 3,73 \\
\hline & & završena osnovna škola & 133 & 3,45 \\
\hline & & završena srednja škola 3 god. & 207 & 3,36 \\
\hline & & završena srednja škola 4 god. & 441 & 2,95 \\
\hline & & VŠS (viša i dodiplomski studij) & 94 & 2,99 \\
\hline & & završen fakultet (dipl. studij) & 81 & 3,00 \\
\hline & & poslijedipl. studij (magisterij, doktorat) & 3 & 1,74 \\
\hline & \multirow{7}{*}{$\begin{array}{l}\text { Svaka vrsta ima } \\
\text { onoliko prava } \\
\text { koliko izbori u } \\
\text { odnosu na druge } \\
\text { vrste }\end{array}$} & nezavršena osnovna škola & 40 & 3,14 \\
\hline & & završena osnovna škola & 133 & 3,29 \\
\hline & & završena srednja škola 3 god. & 207 & 3,21 \\
\hline & & završena srednja škola 4 god. & 441 & 3,09 \\
\hline & & VŠS (viša i dodiplomski studij) & 94 & 3,03 \\
\hline & & završen fakultet (dipl. studij) & 81 & 2,79 \\
\hline & & poslijedipl. studij (magisterij, doktorat) & 3 & 2,24 \\
\hline \multirow{28}{*}{$\begin{array}{l}\text { MOTIVI } \\
\text { POSTUPANJA } \\
\text { PREMA ŽIVOM } \\
\text { SVIJETU }\end{array}$} & \multirow{7}{*}{$\begin{array}{c}\text { Čovjekova je etička } \\
\text { dužnost voditi brigu } \\
\text { o životu životinja i } \\
\text { biljaka }\end{array}$} & nezavršena osnovna škola & 40 & 4,23 \\
\hline & & završena osnovna škola & 133 & 4,03 \\
\hline & & završena srednja škola 3 god. & 207 & 4,04 \\
\hline & & završena srednja škola 4 god. & 441 & 4,10 \\
\hline & & VŠS (viša i dodiplomski studij) & 94 & 4,20 \\
\hline & & završen fakultet (dipl. studij) & 81 & 3,99 \\
\hline & & poslijedipl. studij (magisterij, doktorat) & 3 & 5,00 \\
\hline & \multirow{7}{*}{$\begin{array}{c}\text { Za život životinja i } \\
\text { biljaka čovjek treba } \\
\text { brinuti onoliko } \\
\text { koliko ima od njih } \\
\text { koristi }\end{array}$} & nezavršena osnovna škola & 40 & 3,30 \\
\hline & & završena osnovna škola & 133 & 2,97 \\
\hline & & završena srednja škola 3 god. & 207 & 2,98 \\
\hline & & završena srednja škola 4 god. & 441 & 2,79 \\
\hline & & VŠS (viša i dodiplomski studij) & 94 & 2,75 \\
\hline & & završen fakultet (dipl. studij) & 81 & 2,71 \\
\hline & & poslijedipl. studij (magisterij, doktorat) & 3 & 3,24 \\
\hline & \multirow{7}{*}{$\begin{array}{c}\text { Prema životu } \\
\text { životinja i biljaka } \\
\text { čovjek treba } \\
\text { emotivno postupati }\end{array}$} & nezavršena osnovna škola & 40 & 3,74 \\
\hline & & završena osnovna škola & 133 & 3,75 \\
\hline & & završena srednja škola 3 god. & 207 & 3,71 \\
\hline & & završena srednja škola 4 god. & 441 & 3,77 \\
\hline & & VŠS (viša i dodiplomski studij) & 94 & 3,71 \\
\hline & & završen fakultet (dipl. studij) & 81 & 3,74 \\
\hline & & poslijedipl. studij (magisterij, doktorat) & 3 & 3,75 \\
\hline & \multirow{7}{*}{$\begin{array}{c}\text { Prema životinjama } \\
\text { i bilikama čovjek } \\
\text { se treba odnositi } \\
\text { ovisno o situaciji }\end{array}$} & nezavršena osnovna škola & 40 & 3,71 \\
\hline & & završena osnovna škola & 133 & 3,20 \\
\hline & & završena srednja škola 3 god. & 207 & 3,27 \\
\hline & & završena srednja škola 4 god. & 441 & 3,24 \\
\hline & & VŠS (viša i dodiplomski studij) & 94 & 3,23 \\
\hline & & završen fakultet (dipl. studij) & 81 & 3,06 \\
\hline & & poslijedipl. studij (magisterij, doktorat) & 3 & 2,24 \\
\hline
\end{tabular}


Aritmetičke sredine za „pravo živog svijeta na život“ pokazuju da čovjekovo veće pravo na život preferiraju ispitanici koji nisu završili osnovnu školu $(M=3,73)$, a najmanje ga preferiraju najobrazovaniji ispitanici s magisterijem ili doktoratom ( $M$ $=1,74)$, odnosno naklon prema neslaganju raste kako raste stupanj obrazovanja ispitanika. Ispitanici sa završenim poslijediplomskim studijem najviše su se složili s jednakim pravom životinja i ljudi na život $(M=4,26)$, s time da su svi ispitanici vrlo blizu po vrijednosti aritmetičkih sredina, odnosno naklonjeni slaganju s tom tvrdnjom. Kod izborenog prava najskloniji su ispitanici sa završenom osnovnom školom $(M=3,29)$, a najmanje skloni najobrazovaniji ispitanici $(M=2,24)$, odnosno naklon prema neslaganju raste kako raste stupanj obrazovanja ispitanika.

Za „motive čovjekova postupanja prema živom svijetu“ ispitanici koji nisu završili osnovnu školu preferiraju korist $(M=3,30)$ te situaciju $(M=3,71)$. I tu možemo generalno zaključiti da naklon prema neslaganju raste s porastom obrazovanja, posebno kod utilitarne etike. Ispitanici sa završenim poslijediplomskim studijem u potpunosti su se složili s motivom dužnosti $(M=5,0)$, s time da se i ostali ispitanici slažu s tom tvrdnjom, dok emotivnost kao motiv preferiraju ispitanici sa završenom četverogodišnjom srednjom školom $(\mathrm{M}=3,77)$, ali vrlo blizu toj vrijednosti aritmetičke sredine i ostali su ispitanici.

Tablica 8b.

Razlike u prosjecima „prava na život“ i „motiva postupanja prema živom svijetu“ i obrazovanja (ANOVA)

\begin{tabular}{|c|c|c|c|c|c|c|c|}
\hline & TVRDNJE & L & 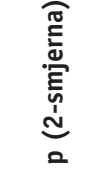 & 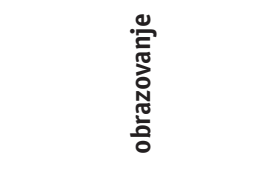 & $\Sigma$ & a & $\frac{v}{1}$ \\
\hline \multirow{4}{*}{ 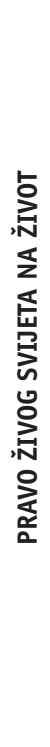 } & \multirow{4}{*}{$\begin{array}{c}\text { Čovjek ima } \\
\text { vece pravo } \\
\text { na život od } \\
\text { životinjskih } \\
\text { vrsta }\end{array}$} & \multirow{4}{*}{10,052} & \multirow{4}{*}{$<0,001$} & $\begin{array}{c}\text { nezavršena osnovna } \\
\text { škola +završena } \\
\text { osnovna škola }\end{array}$ & 3,51 & \multirow{2}{*}{$<0,001$} & \multirow{4}{*}{$\begin{array}{c}\text { nezavršena osnovna } \\
\text { škola+završena } \\
\text { osnovna škola } \\
\text { > završena } \\
\text { 3-godišnja+završena } \\
\text { 4-godišnja srednja } \\
\text { škola, vŠS (viša } \\
\text { i dodiplomski } \\
\text { studij)+ završen } \\
\text { fakultet (dipl. } \\
\text { studij)+ poslijedipl. } \\
\text { studij (magisterij, } \\
\text { doktorat) }\end{array}$} \\
\hline & & & & $\begin{array}{c}\text { završena } \\
\text { trogodišnja+završena } \\
\text { 4-godišnja srednja } \\
\text { škola }\end{array}$ & 3,08 & & \\
\hline & & & & $\begin{array}{l}\text { nezavršena osnovna } \\
\text { škola +završena } \\
\text { osnovna škola }\end{array}$ & 3,51 & \multirow{2}{*}{$<0,001$} & \\
\hline & & & & $\begin{array}{c}\text { VŠS (viša i } \\
\text { dodiplomski studij)+ } \\
\text { završen fakultet (dipl. } \\
\text { studij)+ poslijedipl. } \\
\text { studij (magisterij, } \\
\text { doktorat) }\end{array}$ & 2,97 & & \\
\hline
\end{tabular}




\begin{tabular}{|c|c|c|c|c|c|c|c|}
\hline & TVRDNJE & ᄂ & 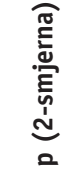 & 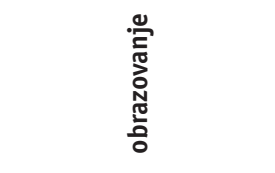 & $\Sigma$ & $=$ & $\frac{v}{n}$ \\
\hline & \multirow{4}{*}{$\begin{array}{l}\text { Svaka vrsta ima } \\
\text { onoliko prava } \\
\text { koliko izbori } \\
\text { u odnosu na } \\
\text { druge vrste }\end{array}$} & \multirow{4}{*}{5,419} & \multirow{4}{*}{0,005} & $\begin{array}{c}\text { nezavršena osnovna } \\
\text { škola +završena } \\
\text { osnovna škola }\end{array}$ & 3,25 & \multirow{2}{*}{0,006} & \multirow{4}{*}{$\begin{array}{c}\text { nezavršena osnovna } \\
\text { škola+završena } \\
\text { osnovna škola, } \\
\text { završena } \\
\text { 3-godišnja+završena } \\
\text { 4-godišnja srednja } \\
\text { škola > VŠS (viša } \\
\text { i dodiplomski } \\
\text { studij)+ završen } \\
\text { fakultet (dipl. } \\
\text { studij)+ poslijedipl. } \\
\text { studij (magisterij, } \\
\text { doktorat) }\end{array}$} \\
\hline & & & & $\begin{array}{c}\text { VŠS (viša i } \\
\text { dodiplomski studij)+ } \\
\text { završen fakultet (dipl. } \\
\text { studij)+ poslijedipl. } \\
\text { studij (magisterij, } \\
\text { doktorat) }\end{array}$ & 2,91 & & \\
\hline & & & & $\begin{array}{c}\text { završena } \\
\text { 3-godišnja+završena } \\
\text { 4-godišnja srednja } \\
\text { škola }\end{array}$ & 3,13 & \multirow{2}{*}{0,039} & \\
\hline & & & & $\begin{array}{c}\text { VŠS (viša i } \\
\text { dodiplomski studij)+ } \\
\text { završen fakultet (dipl. } \\
\text { studij)+ poslijedipl. } \\
\text { studij (magisterij, } \\
\text { doktorat) }\end{array}$ & 2,91 & & \\
\hline \multirow{2}{*}{ 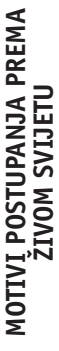 } & \multirow{2}{*}{$\begin{array}{c}\text { Za život } \\
\text { Životinja i } \\
\text { biljaka čovjek } \\
\text { treba brinuti } \\
\text { onoliko koliko } \\
\text { ima od njih } \\
\text { koristi }\end{array}$} & \multirow{2}{*}{3,825} & \multirow{2}{*}{0,015} & $\begin{array}{c}\text { nezavršena osnovna } \\
\text { škola +završena } \\
\text { osnovna škola }\end{array}$ & 3,05 & \multirow{2}{*}{0,026} & \multirow{2}{*}{$\begin{array}{c}\text { nezavršena osnovna } \\
\text { škola+završena } \\
\text { osnovna škola } \\
\text { > vŠS (viša i } \\
\text { dodiplomski } \\
\text { studij)+ završen } \\
\text { fakultet (dipl. } \\
\text { studij)+ poslijedipl. } \\
\text { studij (magisterij, } \\
\text { doktorat) }\end{array}$} \\
\hline & & & & $\begin{array}{c}\text { VŠS (viša i } \\
\text { dodiplomski studij)+ } \\
\text { završen fakultet (dipl. } \\
\text { studij)+ poslijedipl. } \\
\text { studij (magisterij, } \\
\text { doktorat) }\end{array}$ & 2,74 & & \\
\hline
\end{tabular}

* Provedeni su Scheffeov i Tamhaneov T2 post-hoc testovi na $\mathrm{p}=0,05$.

Kako bismo dobili jasnije rezultate, zbrojili smo logične kategorije ispitanika po stupnju obrazovanja prije provođenja ANOVA-e (prikazano u tablici 8b).

Rezultati ANOVA-e pokazuju sljedeće za „pravo živog svijeta na život“:

1. građani/ke sa završenom srednjom školom u trajanju od tri ili četiri godine (M $=3,08)$ te završenom višom školom, fakultetom ili magisterijem/doktoratom $(M$ $=2,97$ ) statistički značajno manje preferiraju čovjekovo veće pravo na život od niže obrazovanih (nezavršena osnovna škola i završena osnovna škola) $(\mathrm{M}=$ 3,51)

2. građani/ke s najviše završenom osnovnom školom te oni koji su završili trogodišnju ili četverogodišnju srednju školu statistički značajno više preferiraju izboreno pravo vrste na život u odnosu na više obrazovane (završena viša škola te diplomski ili dodiplomski studij). 
Nisu pronađene statistički značajne razlike za jednakost čovjeka i ostalog živog svijeta s obzirom na obrazovanje.

Rezultati ANOVA-e pokazuju sljedeće za „motive čovjekova postupanja prema živom svijetu":

1. građani/ke s nezavršenom ili završenom osnovnom školom statistički značajno više preferiraju utilitarnu etiku u odnosu na obrazovanije (završena srednja škola u trajanju od tri i četiri godine, završena viša škola i dodiplomski studij - VŠs te završen diplomski studij na fakultetu - VSS).

Nisu pronađene statistički značajne razlike kod dužnosti, emotivnosti i situacije kao motiva čovjekova postupanja prema živom svijetu s obzirom na obrazovanje.

\section{Tablica 9a.}

Prosječne razlike „prava na život“ i „motiva postupanja prema živom svijetu“ s obzirom na procjenu imovinskog stanja (M)

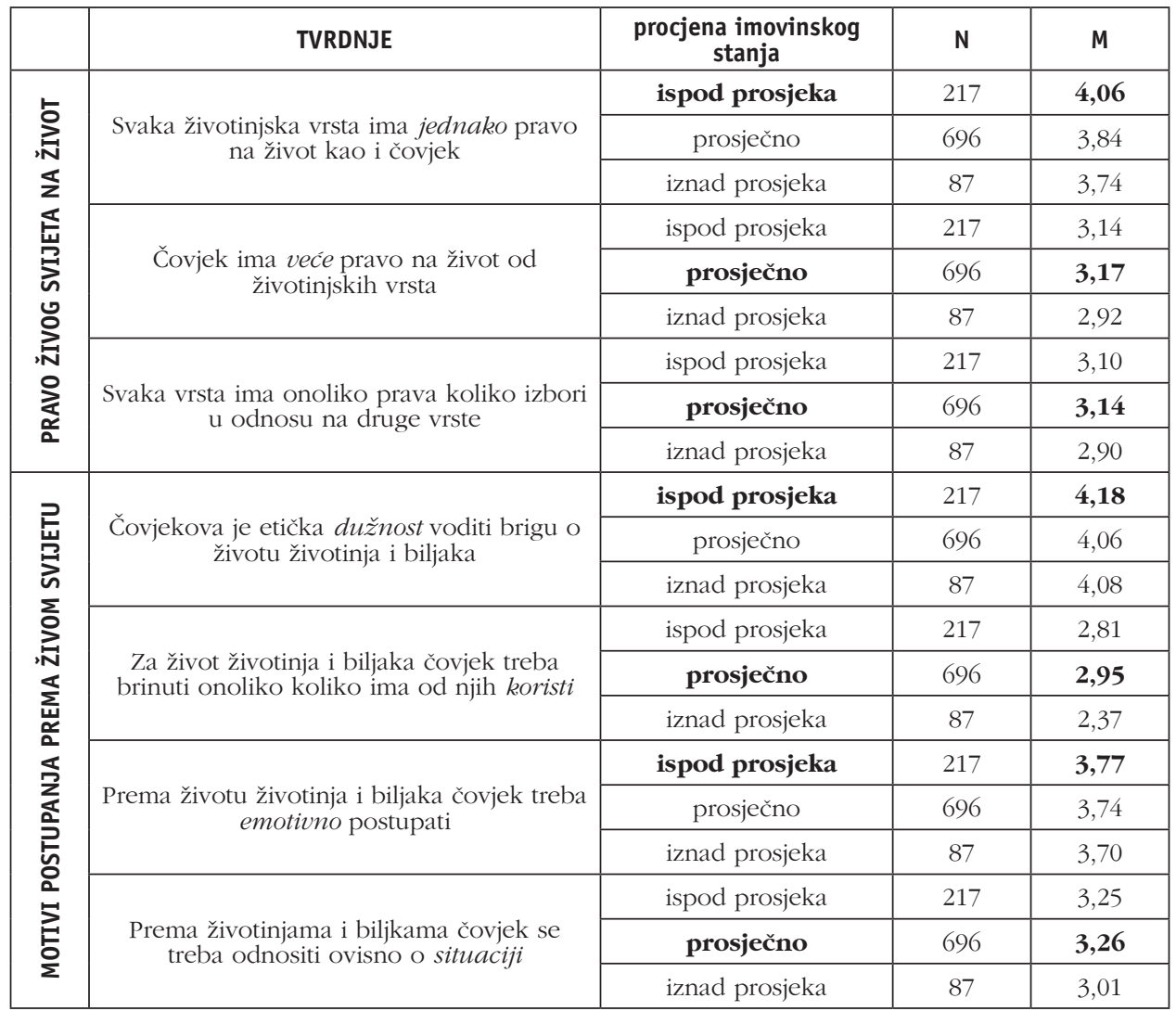

Aritmetičke sredine ukazuju na to da su ispitanici koji su svoje imovinsko stanje procijenili kao ispodprosječno u usporedbi s ostalim ispitanicima iskazali nešto veće slaganje s većim pravom čovjeka na život $(M=4,06)$, a slijede ispitanici koji su svoje imovinsko stanje procijenili kao prosječno, dok se najmanje slažu ispitanici koji su 
svoje imovinsko stanje procijenili kao iznadprosječno. Nasuprot tome, ispitanici koji su svoje imovinsko stanje procijenili kao prosječno preferiraju izboreno $(M=3,14)$ pravo živoga svijeta, a slijede ispitanici koji su svoje imovinsko stanje procijenili kao ispodprosječno, dok se najmanje slažu ispitanici koji su svoje imovinsko stanje procijenili kao iznadprosječno. Za jednakost prava svi su ispitanici naklonjeni, a redom oni koji su svoje imovinsko stanje procijenili kao ispod prosjeka, zatim kao prosječno pa iznad prosjeka.

Što se tiče motiva čovjekova postupanja prema živom svijetu, sve tri grupe ispitanika slažu se s etikom dužnosti, i to redom oni koji su svoje imovinsko stanje procijenili kao ispod prosjeka, zatim iznad prosjeka pa prosječno. Slično je i s emotivnim postupanjem: ispitanici koji su svoje imovinsko stanje procijenili kao ispod prosjeka, zatim prosječno pa iznad prosjeka. Situacijskoj etici najviše naginju ispitanici koji su svoje imovinsko stanje procijenili kao ispod prosjeka pa prosječno, a najmanje, odnosno na sredini skale nalaze se oni koji su svoje imovinsko stanje procijenili kao iznad prosjeka. Konačno, s utilitarnim se pristupom ispitanici ne slažu, s time da se najmanje ne slažu oni koji su svoje imovinsko stanje procijenili kao iznad prosjeka u odnosu na ostale ispitanike.

Tablica 9b.

Razlike u prosjecima „prava na život“ i „motiva postupanja prema živom svijetu“ i procjene imovinskog stanja (ANOVA)

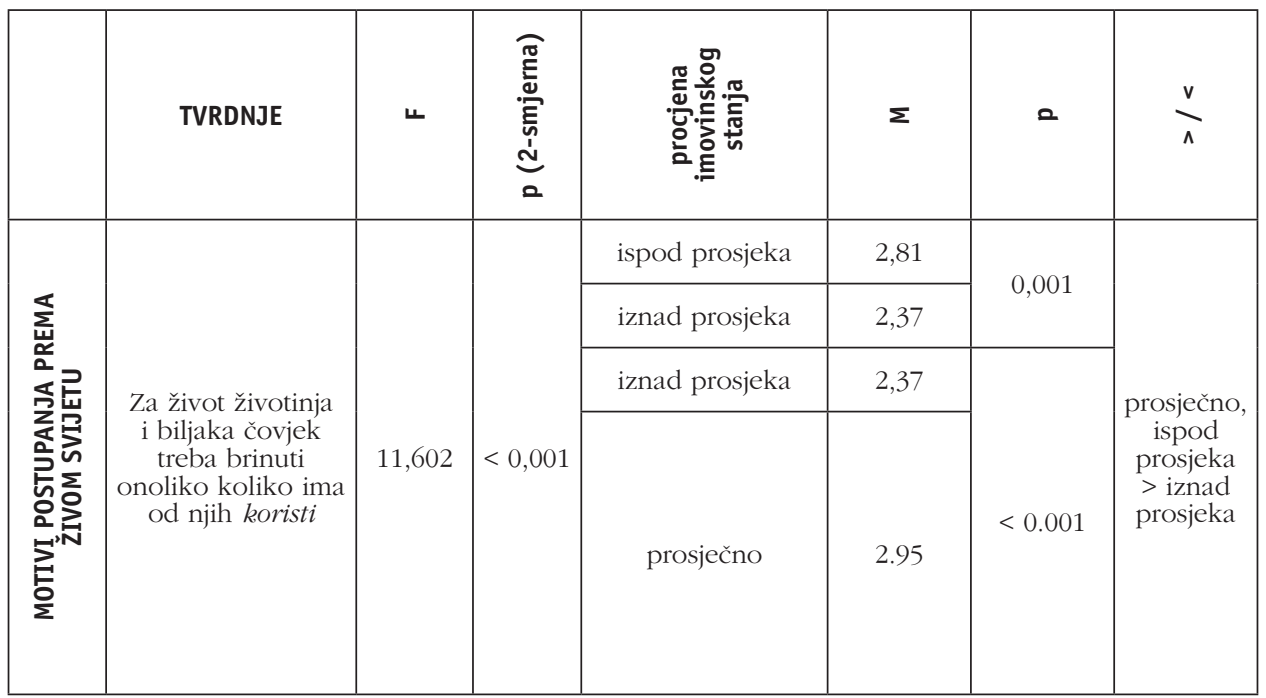

* Provedeni su Scheffeov i Tamhaneov T2 post-hoc testovi na $\mathrm{p}=0,05$.

Rezultati ANOVA-e za motive postupanja prema živom svijetu pokazuju da:

1. građani/ke koji svoje imovinsko stanje procjenjuju kao prosječno te ispodprosječno statistički značajno više preferiraju korisnost kao motivaciju čovjekova postupanja prema živom svijetu od onih koji svoj imovinski status procjenjuju kao bolji od prosjeka. 
Nisu pronađene statistički značajne razlike za dimenziju „prava na život“ te dužnost, emotivnosti i situaciju kao motive čovjekova postupanja prema živom svijetu.

\section{Diskusija i zaključak}

Smatraju li hrvatski građani/ke da ne-ljudska živa bića trebaju imati pravo na život i pod kakvim uvjetima? Na temelju kojih etičkih okvira pristupaju praktičnom djelovanju prema svom živom su-svijetu? Nalaze li se bliže eko/biocentričkoj ili antropocentričkoj strani spektra socioekoloških stavova i ponašanja? To su bila glavna pitanja na koja smo težili odgovoriti u ovom radu, i to putem rezultata provedenog empirijskog istraživanja na reprezentativnom uzorku hrvatskih građana/ki (2014.; N = 1000) operacionalizirajući dvije dimenzije: „pravo živog svijeta na život“ i „motivi čovjekova postupanja prema živom svijetu“. Provedena korelacija dviju ispitanih dimenzija pokazala je da ispitanici koji smatraju da svako živo biće ima jednako pravo na život prema živom svijetu postupaju iz motiva dužnosti i emotivnosti. Odnosno, utilitarni te situacijski motivi razlog su djelovanja prema živom svijetu ispitanika koji preferiraju veće pravo čovjeka na život od životinjskih vrsta te izboreno pravo živih vrsta. Te korelacije odgovaraju našoj polaznoj pretpostavci o smještanju percepcije ispitanika između antropocentričke i eko/biocentričke strane spektra.

Glavna hipoteza za prvi instrument o „pravu na život“, da će ispitanici biti najviše skloni biocentričkoj tezi o jednakosti čovjeka i drugih vrsta, potvrđena je (70,9\% ispitanika složilo se s tom tvrdnjom). Pretpostavili smo kako među građanima/kama postoji određena senzibilnost za pitanja o pravima životinja, na što upućuju i ranija istraživanja, koja pokazuju prevladavajući ekocentrički stav kod socioekoloških orijentacija naših građana u odnosu prema okolišu (Cifrić, 2004.; Cifrić 2006.; Cifrić, 2007.b; Cifrić, Trako Poljak i Klasnić, 2013.). Dio ispitanika (43,4\%) ipak zastupa i antropocentrički stav većeg čovjekova prava, dok su oko izborenog prava više podijeljeni. Nije čudno da dio ispitanika istodobno iskazuje i biocentrički i antropocentrički stav, s obzirom na to da su stavovi prema okolišu nerijetko usko vezani za specifični kontekst i pojedine situacije, zbog čega je i bilo važno ispitati i motivaciju praktičnog djelovanja prema živom svijetu.

Rezultati za pravo na život konzistentni su i s ranijim istraživanjima autora na ovu temu na studentskoj populaciji Sveučilišta u Zagrebu, koja je također iskazivala prevladavajući ekocentrički stav u odnosu prema okolišu (Cifrić, 2006.; Cifrić, 2012.). Bitno je ipak napomenuti da iako populacija hrvatskih građana obuhvaća i populaciju studenata Sveučilišta u Zagrebu, ti rezultati nisu relevantno usporedivi i ne može ih se dovesti u vezu zbog nejednakih parametara, pa je usporedba ovdje više informativnog karaktera. Rezultati iz istraživanja provedenog na studentima 2005. godine ukazivali su na opredjeljenje studenata za stajališta o pravu na život (iako samo nešto više od polovine, $58,1 \%$, a oko trećine, $32,5 \%$, smatralo je da čovjek ima veća prava i 20,6\% zastupalo je stav da pravo živog svijeta na život ovisi o tome koliko se sama izbori) (Cifrić, 2006.). U istraživanju 2010. na studentskoj populaciji distribucija za jednakost bila je više desno asimetrična nego pet godina ranije, odnosno s tvrdnjom se slagala velika većina ispitanika $(73,4 \%)$ ispitanika (Cifrić, 2012.). 
Potvrđena je i druga glavna hipoteza za naš drugi instrument o „motivima postupanja prema živom svijetu“, da će ispitanici biti skloniji dužnosti, a manje skloni emotivnosti, situaciji i korisnosti, odnosno da će biti skloni najviše ekocentričkom stavu od četiriju ponuđenih. Temeljila se ponovno na sličnoj pretpostavci kao i prethodna hipoteza, odnosno na ranijim istraživanjima, koja pokazuju prevladavajući ekocentrički stav kod socioekoloških orijentacija naših građana u odnosu prema okolišu. Stoga se moglo očekivati da se njihove spoznaje o vrijednosti prirodnog svijeta temelje na potrebi njegova očuvanja, a ne samo na temelju koristi ili određene situacije. Iz opće distribuciji rezultata vidljiva je snažno desno asimetrična distribucija slaganja velike većine ispitanika $(81,2 \%)$ s tvrdnjom vezanu za dužnost kao motiv za čovjekovo postupanje prema živom svijetu. Također, prosjek uvjerljivo prelazi četvorku na mjernoj skali od 1 do 5, dok su na svim ostalim tvrdnjama ispitanici bili bliži sredini skale. Ispitanici se u nešto manjoj mjeri, ali ipak slažu i s emotivnim postupanjem prema živom svijetu (63,9\%), dok su odgovori za sljedeće dvije motivacije bliže sredini skale, s time da za postupanje s obzirom na situaciju ispitanici i dalje naginju slaganju, a za korisnost relativnom neslaganju.

Istraživanje na studentskoj populaciji iz 2005. godine pokazuje da je i većina tada ispitanih studenata preferirala dužnost kao motivaciju za čovjekovo postupanje prema Živom svijetu (87,2\%), a taj je broj bio približno jednak $(86,3 \%)$ i kada se istraživanje na studentima ponovilo 2010. godine. Mnogo se manje studenata slaže s tvrdnjom koja se odnosi na korist (2005. 8,5\%, 2010. 10\%) - razliku u odnosu na istraživanje provedeno na reprezentativnom uzorku hrvatskih građana/ki možda možemo pripisati starijem dijelu hrvatskih građana u uzorku, za koje smo pokazali da iskazuju najviše slaganje s tom tvrdnjom u odnosu na ostale dobne skupine.

(Pod)hipoteze postavljene s obzirom na sociodemografska obilježja i orijentacije ispitanika djelomično su potvrđene. S obzirom na spol hipoteza je potvrđena, odnosno provođenjem t-testa dobili smo statistički značajne razlike u smjeru da žene više preferiraju egalitarnost kod prava na život i dužnost kod motiva postupanja prema živom svijetu od muškaraca. Odnosno muškarci statistički značajno više preferiraju veće pravo čovjeka na život u odnosu na žene te korisnost i situacijsku motivaciju čovjekova postupanja prema živom svijetu u odnosu na žene. Godine 2010. studentice su također statistički značajno više preferirale biološku egalitarnost kod prava na život te dužnost kod motiva postupanja prema živom svijetu, a isti rezultat nalazimo i u istraživanju iz 2005. godine.

Međutim, suprotno od pretpostavljenog, rezultati nisu pokazali statističku značajnost preferiranja biološke egalitarnosti i deontološke motivacije mlađih ispitanika. Podhipoteza vezana za dob stoga nije potvrđena. Jedino što iz rezultata možemo tvrditi jest da su stariji ispitanici ( 65 godina i stariji) u odnosu na mlađe (25 i 34 godina) nešto skloniji antropocentričkom stavu kod „prava na život“ jer statistički značajno više zastupaju tvrdnju da čovjek ima veće pravo na život od mlađih ispitanika.

Iako hrvatski građani/ke općenito preferiraju egalitarnost kod prava živih bića, postoje razlike s obzirom na veličinu naselja u kojem žive. Rezultati ANOVA-e pokazuju da ispitanici iz manjih mjesta (sela i manji gradovi) statistički značajno više prefe- 
riraju čovjekovo veće pravo na život od ostalih živih bića u odnosu na ispitanike iz srednjih i većih gradova. Ispitanici iz najmanjih naselja (sela) preferiraju i izboreno pravo vrsta u većoj mjeri od onih iz najvećeg, glavnog grada. Također, iako općenito preferiraju dužnost i nešto manje emotivnost, razlike kod hrvatskih građana/ ki postoje i kod „motiva postupanja prema živom svijetu“. Ispitanici iz najvećeg glavnog grada statistički značajno manje preferiraju korisnost i situacionizam kao motivaciju čovjekova postupanja prema živom svijetu u odnosu na ispitanike iz sela i manjih gradova. Dakle ta je hipoteza djelomično potvrđena - rezultati ne pokazuju da ispitanici iz većih gradova preferiraju egalitarnost kod prava na život te dužnost kod motiva postupanja, već da stanovnici manjih naselja i gradova više preferiraju čovjekovo veće pravo na život od ostalih živih bića i korisnost i situaciju kod motiva postupanja u odnosu na ispitanike iz većih gradova.

Kod regionalne pripadnosti, podhipoteza vezana za povezanost tradicionalnijih i liberalnijih vrijednosti u pojedinim hrvatskim regijama kao i prethodna djelomično je potvrđena - rezultati ne pokazuju da ispitanici iz liberalnijih regija preferiraju egalitarnost kod prava na život te dužnost kod motiva postupanja, već da stanovnici konzervativnijih regija više preferiraju čovjekovo veće pravo na život od ostalih živih bića te korisnost i situaciju kod motiva postupanja u odnosu na ispitanike iz liberalnijih regija.

Podhipoteza vezana za stupanj obrazovanja djelomično je potvrđena. Naime, dok rezultati ne pokazuju da više obrazovani ispitanici statistički značajno više preferiraju biološku egalitarnost te etiku dužnosti, pokazuju, kao što je pretpostavljeno, da su niže obrazovani ispitanici više antropocentrički nastrojeni, odnosno da preferiraju čovjekovo veće pravo na život i utilitarizam (iako ne statistički značajno i situacijsku etiku) kod motiva postupanja prema živom svijetu.

Konačno, imovinski status nije se pokazao statistički značajno povezan s percepcijom hrvatskih stanovnika o pravu živog svijeta na život te motivima postupanja prema živom svijetu, osim za etiku korisnosti, pri čemu ispitanici koji procjenjuju svoj imovinski status kao ispodprosječan i prosječan značajno više preferiraju korisnost kao motivaciju čovjekova postupanja prema živom svijetu od ispitanika koji svoj imovinski status procjenjuju kao bolji od prosjeka.

Zaključno, rezultati provedenog empirijskog istraživanja pokazuju da kod stavova i motivacija etičnog postupanja prema ne-ljudskim bićima među hrvatskim građanima/kama prevladava eko/biocentrički stav, što potvrđuje naše dvije glavne hipoteze. Međutim rezultati ukazuju i na činjenicu da taj stav nije u potpunosti stabilan, odnosno da je bliži biocentričkoj ili antropocentričkoj strani spektra ovisno o različitim okolnostima. To je još jasnije kod ispitanog praktičnog djelovanja prema živom svijetu, gdje je vidljivo da ispitanici više naginju biocentričkim motivacijama dužnosti i emotivnosti (koje su u našem istraživanju i statistički značajno pozitivno korelirane s egalitarizmom u pravima živog svijeta na život), a tek onda situaciji i najmanje korisnosti. No rezultati ukazuju i na razlike među ispitanicima s obzirom na sociodemografska obilježja, koja nam pokazuju koji su prediktori ekocentričkih i antropocentričkih stavova prema su-svijetu, što je samo donekle sukladno našoj 
trećoj glavnoj hipotezi s podhipotezama. Odnosno, s obzirom na rezultate, spol se pokazao dobrim prediktorom ekocentričkih stavova biološkog egalitarizma i etike dužnosti (kojima su sklonije žene u odnosu na muškarce) te antropocentričkih stavova antropocentričkog ekscepcionalizma te situacijske etike i utilitarizma (muškarci u odnosu na žene). Veličina mjesta stanovanja, tradicionalnije ili liberalnije orijentirane regije te stupanj obrazovanja pokazali su se dobrim prediktorima antropocentričkih stavova (ekscepcionalizam i izboreno pravo) te antropocentričke motivacije ponašanja (situacionizam i utilitarizam) - manja mjesta u odnosu na veća (ruralno u odnosu na urbano stanovništvo), konzervativnije regije te niže obrazovani ispitanici. Dob se pokazala značajnim prediktorom samo kod antropocentričkih stavova (stariji u odnosu na mlađe), ali ne i antropocentričke motivacije ponašanja te ne i ekocentrizma u stavovima i motivaciji djelovanja. Tako se ni imovinski status nije pokazao značajnijim prediktorom, osim kod antropocentričke (utilitarne) motivacije djelovanja čovjeka prema okolišu (imovinski manje imućni i prosječno imućni u odnosu na imućnije). Nada je da će dobiveni rezultati poslužiti produbljenju našeg razumijevanja odnosa hrvatskog društva prema živom svijetu koji nas okružuje, ali potencijalno i otvoriti prostor za smjernice za praktično djelovanje, koje bi boljom edukacijom te razvojem usmjerenijih politika mogle pomoći unaprjeđenju tog odnosa.

\section{Literatura}

1. Cifrić, I. (1996). Tranzicija i transformacija - između norme i prakse. Socijalna ekologija, 5 (2): 135-153.

2. Cifrić, I. (2004). Orijentacijski identitet. Socijalnoekološke orijentacije kao obilježja identiteta. Socijalna ekologija, 13 (3-4): 221-256.

3. Cifrić, I. (2006). Odnos prema životu: kontekst biocentrične orijentacije. Socijalna ekologija, 15 (1-2): 43-79.

4. Cifrić, I. (2007a). Pravo životinjskih vrsta na život. Sociologija i prostor, 45 (1/175): 3-27.

5. Cifrić, I. (Ur.). (2007b). Relacijski identiteti: Prilozi istraživanju identiteta hrvatskog društva. Zagreb: Biblioteka Razvoj i okoliš.

6. Cifrić, I. i Trako Poljak, T. (2012). Percepcija prava Živoga svijeta i motivi čovjekova djelovanja. Socijalna ekologija, 21 (2): 123-153.

7. Cifrić, I.; Trako Poljak, T. i Klasnić, K. (2013). Hrvatski identitet u promjeni. Relacijski identiteti 2. Zagreb: Biblioteka Razvoj i okoliš.

8. Coetzee, J. M. (2004). Život životinja. Zagreb: AGM.

9. Darwin, C. (2008 [1859]). Postanak vrsta. Zagreb: Naklada Lijevak.

10. Devall, B. (2001). Deep Ecology: Living as if Nature Mattered. USA: Gibbs Smith.

11. Ilišin, V. i Gvozdanović, A. (2016). Struktura i dinamika vrijednosti mladih u Hrvatskoj, u: Sekulić, D. (Ur.). Vrijednosti u hrvatskom društvu. Zagreb: Centar za demokraciju i pravo Miko Tripalo.

12. Kant, I. (1999 [1785]). Metafizika ćudoređa. Zagreb: Matica Hrvatska.

13. LaChapelle, D. (1991). Educating for Deep Ecology. Journal of Experiential Education, 14 (3): 18-22.

14. Naess, A. (1973). The Shallow and the Deep, Long-range Ecology Movements: A Summary. Inquiry, 16 (Spring): 95-100. 
15. Naess, A. (1989). Ecology, Community, and Lifestyle: An Outline of an Ecosophy. Cambridge, UK: Cambridge University Press.

16. Nedić, T. (2018). Pravni sustav zaštite života, zdravlja, i dobrobiti životinja bioetički pristup u pravnom okviru. Socijalna ekologija, 27 (1): 71-94.

17. Regan, T. (2004). The Case for Animal Rights. Berkeley: University of California Press.

18. Roszak, T.; Gomes, M. E. and Kanner, A. D. (Ed.) (1995). Ecopsychology: Restoring the Earth, Healing the Mind. New York: Sierra Club Books.

19. Sessions, G. (Ed.). (1995). Deep Ecology for the 21 $1^{\text {st }}$ Century. Boston: Shambhala.

20. Shepard, P. (1996). Traces of an Omnivore. Washington: Island Press.

21. Shepard, P. (1997). The Others: How Animals Made Us Human. Washington: Island Press.

22. Singer, P. (1998). Oslobođenje životinja. Zagreb: IBIS Grafika.

23. Van Liere, K. D. and Dunlap, R. E. (1980). The Social Bases of Environmental Concern: A Review of Hypotheses, Explanations and Empirical Evidence. Public Opinion Quarterly, 44 (2): 181-197.

24. Visković, N. (1996). Životinja i čovjek: prilog kulturnoj zoologiji. Split: Književni krug.

25. Zelezny, L. C.; Poh-Pheng, C. and Aldrich, C. (2000). Elaborating on Gender Differences in Environmentalism. Journal of Social Issues, 56 (3): 444-467. 
Izvorni znanstveni rad

Tijana Trako Poljak

University of Zagreb, Faculty of Humanities and Social Sciences, Department of Sociology, Croatia

e-mail: ttrako@ffzg.hr

Ivan Cifrić

Zagreb, Croatia

Antonija Bukvić-Letica

Zagreb, Croatia

Tea Tomić

Zagreb, Croatia

\title{
The Rights of the Living World, Ethical Principles and Human Attitudes Toward the Natural Environment
}

\begin{abstract}
In order to better understand and attempt to resolve today's pressing environmental issues, we need a deper understanding of the ethical principals that guide the decisions of involved actors. The relationship between humans and their environment, including their practical behaviour toward the living and non-living world, is guided by ethical principles which are anthropocentric or eco/bio/centric in nature. The goal of this paper is to examine the ethical foundation of Croatian citizens' relationship toward their living environment through their perception of 1) the right of the living beings to life and 2) the motives behind human care for the living world (plants and animals). In the theoretical part of the paper, the idea of "the right of the living world to live" is defined by three dominant theoretical approaches: (biological) egalitarianism, anthropocentric exceptionalism (human domination) and the fight for survival (natural competition). Furthermore, "the motives behind human behaviour toward the living world" are defined by four key ethical approaches: deontological ethics (duty), utilitarian ethics (usefulness), emotions (feelings) and situational ethics (circumstances). In the methodological part of the paper, the results from the empirical research conducted on the representative sample of Croatian citizens $(2014, \mathrm{~N}=1000)$ are presented. The results reveal that most respondents prefer 1)"egalitarianism" (animal species have the same right to life as humans) and 2)"deontological ethics"as the main motive for human behaviour toward the living world. In addition, statistically significant differences are found in relation to respondents' socio-demographic characteristics. Finally, we offer a brief comparison of these results with those from the previous research done in 2005, 2007 and 2010 on a narrower student sample.
\end{abstract}

Key words: anthropocentrism, ecocentrism, animal rights, egalitarianism, deontological ethics. 